\title{
Review
}

\section{Regulatory Peptides in Asthma}

\author{
Katarzyna Kaczyńska *(D), Dominika Zając (), Piotr Wojciechowski (ํ) and Monika Jampolska
}

check for

updates

Citation: Kaczyńska, K.; Zając, D.; Wojciechowski, P.; Jampolska, M. Regulatory Peptides in Asthma. Int. J. Mol. Sci. 2021, 22, 13656. https:/ / doi.org/10.3390/ijms222413656

Academic Editor: Daniel P. Potaczek

Received: 3 December 2021

Accepted: 19 December 2021

Published: 20 December 2021

Publisher's Note: MDPI stays neutral with regard to jurisdictional claims in published maps and institutional affiliations.

Copyright: (c) 2021 by the authors. Licensee MDPI, Basel, Switzerland. This article is an open access article distributed under the terms and conditions of the Creative Commons Attribution (CC BY) license (https:/ / creativecommons.org/licenses/by/ $4.0 /)$.
Department of Respiration Physiology, Mossakowski Medical Research Institute, Polish Academy of Sciences, Pawińskiego 5 St., 02-106 Warsaw, Poland; dzajac@imdik.pan.pl (D.Z.); pwojciechowski@imdik.pan.pl (P.W.); mjampolska@imdik.pan.pl (M.J.)

* Correspondence: kkaczynska@imdik.pan.pl

\begin{abstract}
Numerous regulatory peptides play a critical role in the pathogenesis of airway inflammation, airflow obstruction and hyperresponsiveness, which are hallmarks of asthma. Some of them exacerbate asthma symptoms, such as neuropeptide $Y$ and tachykinins, while others have ameliorating properties, such as nociception, neurotensin or $\beta$-defensin 2 . Interacting with peptide receptors located in the lungs or on immune cells opens up new therapeutic possibilities for the treatment of asthma, especially when it is resistant to available therapies. This article provides a concise review of the most important and current findings regarding the involvement of regulatory peptides in asthma pathology.
\end{abstract}

Keywords: regulatory peptides; asthma; airway hyperreactivity; inflammation

\section{Introduction}

Bronchial asthma is a heterogeneous disease characterized by chronic inflammation of the airways, diagnosed on the basis of characteristic symptoms, such as tightness in the chest, wheezing, dyspnea and cough. These symptoms are accompanied by reversible, either spontaneously or by treatment, expiratory airway obstruction. Asthma, regarded as a global health problem, affects more than 300 million people worldwide, but the mechanism of this pathology has not been completely elucidated [1,2].

The inflammatory process in the airway involves a number of cells, e.g., eosinophils, neutrophils, T lymphocytes, macrophages, mast cells and epithelial cells; and many endogenous inflammatory mediators, such as histamine, cysteinyl leukotrienes and cytokines [3].

Interestingly, many other endogenous mediators, such as regulatory peptides not necessarily directly related to respiratory tract functioning, have been implicated in mediation of asthma related inflammatory process and airway hyperreactivity (AHR) [4,5].

Some of the regulatory peptides, including neuropeptides, are present in the respiratory system. They are produced by pulmonary neuroendocrine cells (bombesin-like peptides and serotonin), the only innervated airway epithelial cells [6]; and autonomic airway fibers innervating airway muscles, blood vessels and lungs (substance P (SP), neurokinin A (NKA) and vasoactive intestinal polypeptide (VIP)) [5]. Neuropeptides can act directly through their receptors and regulate airway smooth muscle tone, bronchial blood flow and airway secretion or act on inflammatory cells, contributing in this way to inflammatory process and ventilation in asthma pathology (Figure 1) [5,7-9]. Their impact on asthma symptoms can be either soothing, as for neurotensin [10], or aggravating, as for neuropeptide $Y$ [11]. Another group of regulatory peptides are adipokines, which are hormones secreted by adipose tissue, namely adiponectin, leptin and resistin; and hormones related to the feeling of hunger and satiety, such as ghrelin. Changes in the physiological balance between proinflammatory and anti-inflammatory adipokines, as well as changes in the physiological balance of adipokines and proinflammatory cytokines secreted by adipose tissue, may increase the risk of obesity-related asthma by reducing the natural development of immune tolerance $[12,13]$. 


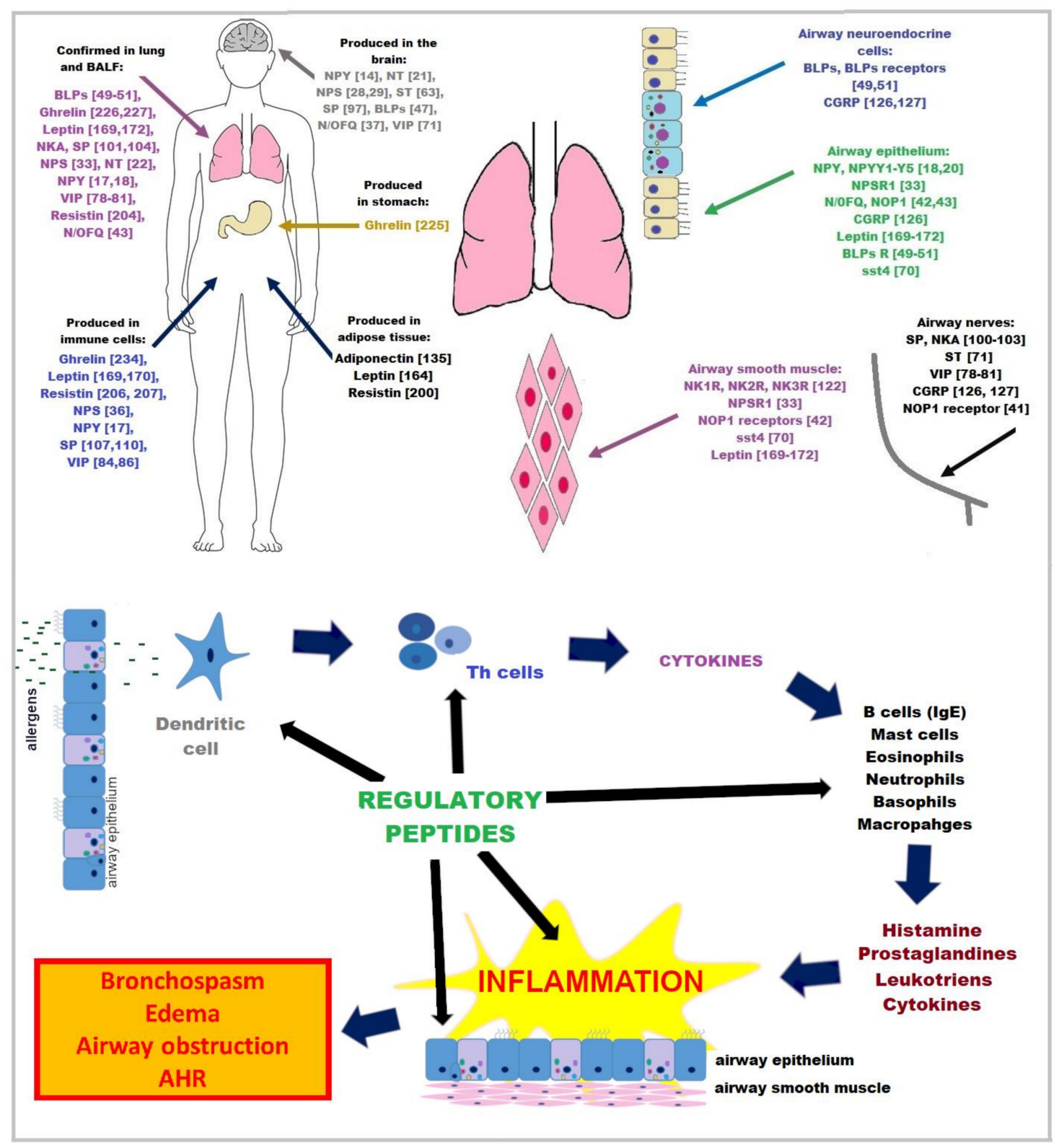

Figure 1. Localization of asthma-related regulatory peptides and their receptors in the body and in the lungs (upper panel). Lower panel shows the locations of regulatory peptide interactions that may influence the course of asthma. NPY, neuropeptide Y; NPS, neuropeptide S; BLPs, bombesin-like peptides; NKA, neurokinin A; SP, substance P; VIP, vasoactive intestinal polypeptide; N/OFQ, nociception; CGRP, calcitonin gene-related peptide.

In this concise review, we summarize major findings, including the recent ones, that are concerned on regulatory peptides involvement in asthma pathology (Table 1). Since successful control of the asthma symptoms is still a challenge, some of the results described may provide helpful guidance in the development of new therapeutic approaches for the treatment of asthma.

\section{Neuropeptides}

\subsection{Neuropeptide Y (NPY)}

Neuropeptide Y (NPY), a 36-amino acid peptide, is the most widespread peptide in neurons of the central and peripheral nervous system, acting through six subtypes of $\mathrm{G}_{\mathrm{i}} / \mathrm{G}_{\mathrm{O}}$-coupled receptors, from Y1 to Y6 [14]. Its particularly high abundance is found in noradrenergic neurons, from which NPY co-released with norepinephrine (NE) is involved 
in the regulation of vascular tone. In the brain, this compound is engaged in feeding regulation, neuroendocrine secretion and anxiety and stress responses [15,16].

NPY has been implicated as an important regulator of inflammation, acting mainly through the NPY-Y1 receptor expressed by various immune cells to exacerbate allergic airway inflammation. The absence of NPY and NPY-Y1 receptor signaling protected mice from developing airway inflammation and delayed-type hypersensitivity [17]. These findings were confirmed in further studies in which NPY levels in bronchoalveolar fluid were elevated in an allergic model of asthma, accompanied by increased NPY expression localized to macrophages in the lung tissue. Furthermore, NPY-Y1 and -Y5 receptors were overexpressed by inflammatory and structural cells in lung tissue [18]. The critical role of NPY in the development of airway hyperresponsiveness (AHR), airway inflammation, airway dendritic cell accumulation and promotion of the type 2 immune response has been further supported [11]. The authors also demonstrated that the NPY-Y1 receptor antagonist (BIBO-3304) was able to reduce AHR and airway inflammation in wild-type mice, implying a new therapeutic avenue for the treatment of asthma.

In addition to its immunological effects on the asthmatic process, NPY has also been shown to induce direct contraction in isolated guinea-pig airways [19]. Increased NPY expression in the airway epithelium of transgenic mice was also able to induce the AHR phenotype without airway inflammation [20].

\subsection{Neurotensin (NT)}

Neurotensin is a 13 amino acid gut-brain peptide hormone, distributed throughout the central nervous system, where it is associated with dopaminergic system, regulates hypothermia, pain perception, stress responses and locomotor activity. In the periphery, neurotensin is found in enteroendocrine cells of the small intestines [21]. The pulmonary parenchyma appears to be an important site of NT metabolism, because NT concentrations increase in mixed venous blood after passage through it, both in normal and asthmatic subjects [22]. To date, there are only a few papers suggesting a potential role for this neuropeptide in asthma. Two articles from the 1990s, recounting in vitro experiments, showed that NT was a potent constrictor of airway muscles [23,24], while a later study showed the opposite effect in the form of NT-mediated inhibition of guinea pig cholinergic and noncholinergic bronchial ring contraction evoked by electrical field stimulation [25]. Consistent with a recent article about the latest in vivo study, which applied NT in non-allergic murine asthma model, showed that NT was very effective in attenuating airway hyperreactivity and inflammatory responses. Reduction in inflammatory cell number (macrophages and neutrophils) and TNF- $\alpha$ level in bronchoalveolar lavage fluid (BALF) and airway hyperreactivity was due to NTS1 receptor activation [10]. In the same model of asthma, a chimeric peptide constructed from modified NT and endomorphin-2 pharmacophores also reduced airway hyperresponsiveness, inflammatory cells influx in BALF, concentration of mouse mast cell protease, malondialdehyde, NF- $\mathrm{KB}$ expression and secretory phospholipase 2 activity in lung tissue, as well as production of pro-inflammatory cytokines in BALF and lung [26]. Some of the chimera effects depended also on NTS1 receptor stimulation [27].

\subsection{Neuropeptide S (NPS)}

NPS-expressing cells are found in amygdala, hypothalamus and pericoerulear region of the brainstem. This 20 amino acids peptide is involved in modulation of arousal and wakefulness, feeding behavior, anxiety responses and analgesia [28,29]. NPS has been implicated to have a key role in asthma pathogenesis, as a number of single nucleotide polymorphisms within NPSR1 receptor were shown to be associated with a higher genetic risk and prevalence of asthma [30,31]. In the earlier study, lung NPS receptors were reported to be upregulated in a mouse model of ovalbumin (OVA)-induced airway inflammation [32], which was confirmed by increased expression of the NPSR-B isoform in bronchiolar smooth muscle and epithelial cells of asthmatics [33]. The role of NPSR1 in childhood asthma is also indicated by higher levels of NPSR1 protein in the plasma of chil- 
dren with mild intermittent asthma compared to healthy controls [34]. It was further shown that NPS applied intracerebroventricularly was able to reduce airway responsiveness to methacholine in experimental animals, most likely through a CNS-mediated pathway connecting respiratory and stress responses [35]. NPS receptor has been also shown as a modulator of immune cell function. Eosinophils from patients with severe asthma and elevated serum IgE levels expressed higher levels of NPS receptor protein and responded to NPS by enhanced migration and adhesion molecule expression [36].

Despite the above studies, there is a lack of direct evidence for a role of NPS receptors in the development of asthma, especially considering that NPSR1 deletion in mice did not result in changes in allergic airway inflammation and hyperresponsiveness [35].

\subsection{Nociceptin (N)/Orphanin (OFQ)}

The heptadecapeptide nociceptin, also known as orphanin FQ, is an endogenous ligand for the nociceptin opioid-like receptor-1 (NOP1). Nociceptin and its receptor are found in central and peripheral nervous tissue, where they are involved in nociception, mood disorders, anxiety, memory regulation, food intake and immunomodulation [37]. They also have been shown to play a critical role in the pathogenesis of airway inflammation, hyperresponsiveness and bronchoconstriction [38]. With regard to the latter, nociceptin inhibited substance $P$ release and non-adrenergic non-cholinergic contraction in guinea-pig isolated trachea [39]. D'Agostino et al. [40] demonstrated in vitro that a decrease in endogenous $\mathrm{N} / \mathrm{OFQ}$, or the absence of its receptor, results in an increase in capsaicin-induced bronchoconstriction, indicating the ability of this neuropeptide to modulate bronchoconstriction by affecting sensory fibers.

In the lungs, NOP receptors were expressed on the bronchial afferent nerve fibers of guinea pigs [41], and in human and mouse immune and structural airway cells [42]. N/OFQ immunoreactivity appeared to be increased in biopsies of asthmatic human lungs, mostly in sub-epithelial and extracellular matrix areas. Its elevated level was also found in severe asthma human sputum. The article suggested that the concentration of endogenous N/OFQ, although elevated in asthma, is too low to modulate the immune system and AHR [43]. In fact, administration of NOP receptor selective agonist UFP-112 during sensitization phase significantly reduced the AHR and lung eosinophilic infiltration in allergen-sensitized mice [44]. Subsequent research demonstrated, as well, that exogenously administered N/OFQ in experimental OVA-induced asthma reduced airway constriction and inflammation by diminishing eosinophil influx, production of Th2 cytokines and mucin [43]. Further, modulation of Th2 mediated allergic response by N/OFQ was demonstrated with its direct activity on dendritic cells [45]. Recent studies in an OVA-induced allergic asthma model have confirmed the beneficial effects of N/OFQ on disease symptoms, not only protecting against inflammation, but also against mechanical damage and remodeling of small airways [46].

\subsection{Bombesin (BN)}

Bombesin (BN), an amidated tetradecapeptide, was at first isolated from the skin of European frog [47]. Two mammalian bombesin-like peptides (BLPs) having a widespread distribution in the central nervous system (CNS) and gastrointestinal (GI) tract [47] were discovered so far: gastrin-releasing peptide (GRP), with a higher affinity towards Gprotein-coupled GRP receptor, and neuromedin B (NMB) binding to the NMB receptor. The third bombesin receptor, an orphan receptor BRS-3, has no identified native ligand [48]. Moreover, mRNA for all BPLs receptors is present in mammalian airway epithelium, mucosal neuroendocrine and non-neuroendocrine cells [49-51]. BLPs and their receptors are suspected to be involved in developing airway hyperreactivity [52] and airway allergic disease $[53,54]$. It was displayed that BN and related agonists produced a potent contractile response in guinea pig peripheral airways in vitro via a direct effect on bronchial smooth muscle GRP-preferring receptor [52]. BLPs, especially BN, have proinflammatory properties; when administered into the trachea in mice or used in vitro, they induce mast cell 
proliferation and chemotaxis [54]. GRP activates specific signaling pathways that promote neutrophil migration, which was blocked by RC-3095, a selective GRPR antagonist [55-57]. GRP receptor blockade may serve as a broad spectrum of anti-inflammatory therapy for asthma [58,59], since reduced neutrophilic inflammation and cytokine production triggered by ozone were reduced with GRP blocking agent or antibody [53].

A recent investigation has revealed that BRS-3 may be a contributing factor to the pathophysiology of bronchial asthma [60]. BRS-3 activation in human bronchial epithelial cells (HBECs) was reported to promote TGF- $\beta 1$ mediated activation of fibroblasts, thereby promoting the airway remodeling [61]. In contrast, another study in an animal model of asthma showed a beneficial effect of BRS-3 activation on asthma by promoting antigen uptake by HBECs and subsequently increasing T-cell proliferation and Th1 differentiation [62]. This shows another pathway of affecting asthma via stimulation of BRS-3 receptors and inhibition of Th2 inflammation response in airway mucosa.

\subsection{Somatostatin (ST)}

Somatostatin is widely expressed both in the CNS [63] and in the peripheral tissues [64,65]. Its action is mediated by five somatostatin receptor subtypes, from sst 1 to sst5, which belong to the G-protein-related receptor family [66-68], all of which are expressed in the lung [69]. The most relevant receptor in asthma pathology appears to be sst4, whose mRNA expression has been confirmed on mouse and human bronchial epithelial, vascular endothelial and smooth muscle cells [70]. A study by Helyes et al. [71] showed that somatostatin released from sensory nerve terminals in response to activation of vanilloid 1 (TRPV1) receptors/ion channels, during lung endotoxin-induced airway inflammation, inhibited inflammation and consequent bronchial hyperreactivity. Research on the application of selective somatostatin sst4 receptor synthetic agonists in ovalbumin-induced airway inflammation has reported reduced granulocyte recruitment, infiltration of eosinophil cells, mucosal oedema formation, enhanced mucus production, destruction of the epithelial cells and AHR to carbachol. These effects can be possibly mediated via that prejunctional somatostatin sst 4 [72] receptor, whose stimulation produces the inhibition of the release of the proinflammatory neuropeptides, such as substance $\mathrm{P}$ and calcitonin-gene-related peptide (CGRP), from the peripheral terminals of capsaicin-sensitive sensory nerve endings [73,74]. In summary, the use of native somatostatin in the treatment of asthma is limited because of its wide range of action through all receptors, but selective agonists acting on the SST4 receptor offer some promise $[65,72]$.

Table 1. Regulatory peptides involved in mediating asthma symptoms. A description of the action of a particular peptide and the receptors through which it acts (animal studies).

\begin{tabular}{|c|c|c|c|c|}
\hline Peptide (Sequence) & Asthma Suppression & Asthma Promoting & Receptors & References \\
\hline Neuropeptide Y (NPY) & & Induction of AHR & & {$[19,20]$} \\
\hline $\begin{array}{l}\text { (YPSKPDNPGEDAPAEDLARYYSAL- } \\
\text { RHYINLITRQRY) }\end{array}$ & & $\begin{array}{l}\uparrow \text { AHR and airway } \\
\text { inflammation }\end{array}$ & NPY-Y1 & {$[11,19]$} \\
\hline $\begin{array}{l}\text { Neurotensin (NT) } \\
\text { (XLYENKPRRPYIL) }\end{array}$ & $\downarrow$ AHR and inflammation & & NTSR1 & {$[10,26,27]$} \\
\hline $\begin{array}{c}\text { Neuropeptide S (NPS) } \\
\text { (SFRNGVGTGMKKTSFQRAKS) }\end{array}$ & $\downarrow$ AHR & & & [35] \\
\hline $\begin{array}{l}\text { Nociceptin (N)/Orphanin OFQ } \\
\text { (FGGFTGARKSARKLANQ) }\end{array}$ & $\begin{array}{l}\downarrow \text { airway constriction } \downarrow \\
\text { inflammation }\end{array}$ & & NOP1 & {$[40,43,44,46]$} \\
\hline \multirow{4}{*}{ Bombesin (BN) (XQRLGNQWAVGHLM) } & & \multirow{4}{*}{$\begin{array}{c}\uparrow \text { neutrophilic inflammation } \\
\uparrow \text { cytokine production } \\
\uparrow \text { contractile response } \\
\uparrow \text { mast cell proliferation and } \\
\text { chemotaxis } \\
\uparrow \text { airway injury and } \\
\text { re-modeling }\end{array}$} & GRPR & {$[53,55-57]$} \\
\hline & & & GRPR & [52] \\
\hline & & & & [54] \\
\hline & & & BRS-3 & {$[58,61]$} \\
\hline $\begin{array}{c}\text { Somatostatin (ST) } \\
\text { (AGCKNFFWKTFTSC) }\end{array}$ & $\downarrow$ inflammation and AHR & & sst4 & [71-74] \\
\hline
\end{tabular}




\subsection{Vasoactive Intestinal Polypeptide (VIP)}

Vasoactive intestinal polypeptide (VIP), a peptide messenger present in the central and peripheral nervous systems, is involved in a number of biological functions [75], including smooth muscle relaxation, regulatory hormone secretion and regulation of the immune response [76,77]. In the respiratory system, VIP-immunoreactive nerves are present in the human lung and nasal mucosa; and in the smooth muscle layer, airway glands and the walls of pulmonary and bronchial vessels [76,78-81]. VIP released from inhibitory nonadrenergic noncholinergic (i-NANC) nerves acts as a potent smooth muscle relaxant inducing bronchodilation (Figure 2) and vasodilation [82]; however, during allergic condition, VIP effects can be attenuated by released inflammatory mediators that result in AHR [83].

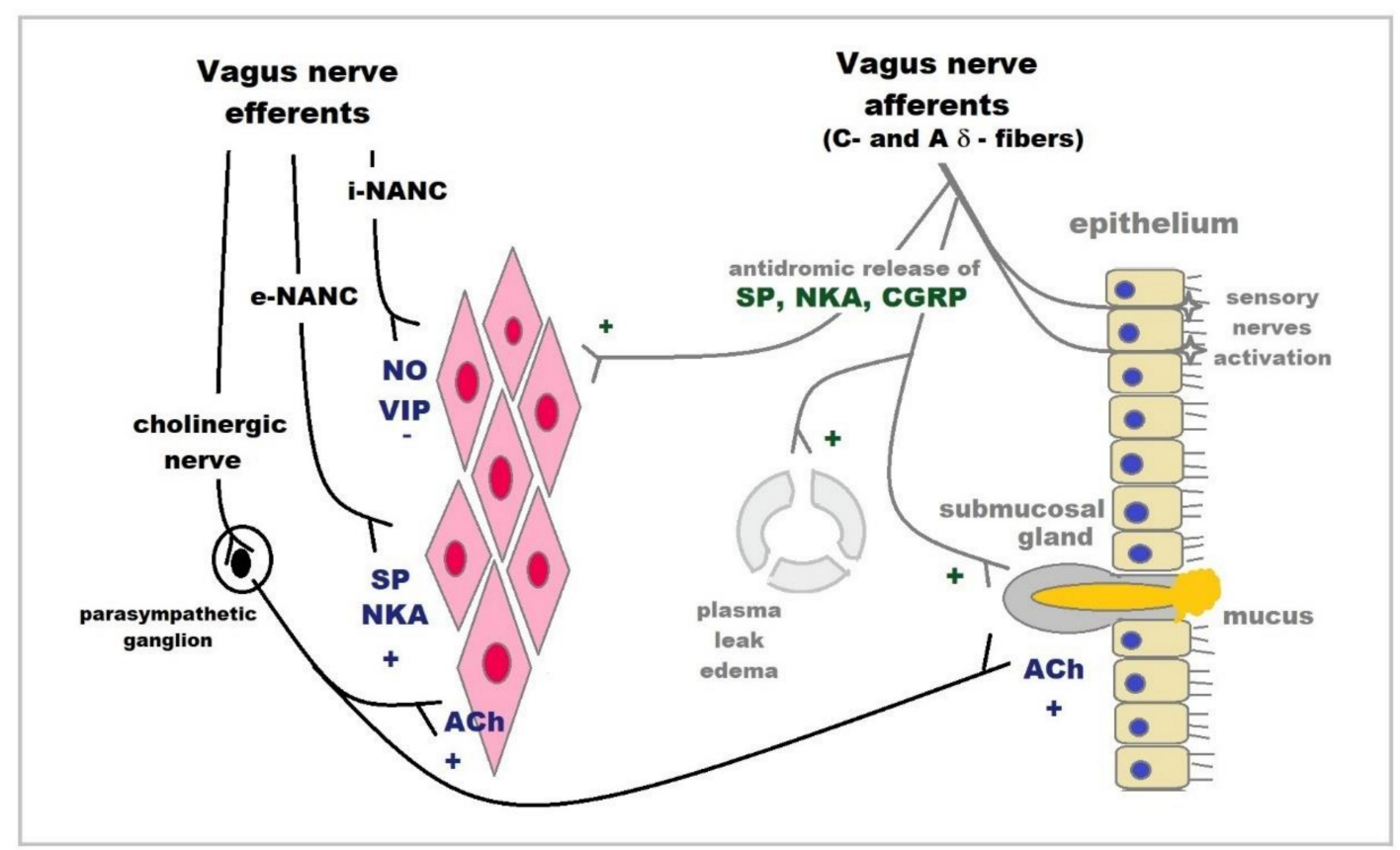

Figure 2. Neuropeptides secreted by i-NANC (VIP) and e-NANC (SP, NKA) efferent fibers of the vagus nerve and returning collaterals of vagus nerve sensory fibers (SP, NKA and CGRP) in the course of asthma; (-) means smooth muscle retraction and bronchodilation; (+) means smooth muscle contraction, bronchoconstriction, mucus hypersecretion, plasma exudation and edema.

Although VIP is mainly secreted by nervous tissue, it is also produced by several immune cells, such as eosinophils, mast cells and lymphocytes [84-86]. The VIP immune response is mediated by specific receptors, namely vasoactive intestinal peptide receptor type 1 (VPAC-1) and type 2 (VPAC-2) [87]. VIP is a well-known anti-inflammatory factor that regulates the production of both anti- and pro-inflammatory mediators and the endogenous oxidant/antioxidant balance; reduces IL- $1 \beta$-induced neutrophil recruitment to the airways; inhibits the activation of macrophages, dendritic cells and microglia [88-90]; and promotes a type 2 immune response via the VPAC-2 receptor, which is highly expressed on activated $\mathrm{T}$ cells and ILC2s $[77,91,92]$. Transgenic mice with high constitutive VPAC2 expression in T cells showed immediate-type allergic reaction, in contrast to mice with knockout of the VPAC2 receptor [91-93]. On the other hand, inhalation with VPAC2 agonist has been shown to induce bronchodilatation [94]. A role for VIP in the development of asthma has also been demonstrated in studies involving mice lacking the VIP gene that exhibited spontaneous asthma features, such as peribronchial airway inflammation and the production of pro-inflammatory cytokines and AHR, which was partially reduced by administration of exogenous VIP [95]. Therefore, the development of long-acting VIP analogs with strong 
bronchodilatory effects $[76,82]$ or modulators of the VIP-VPAC2 signaling pathway may provide clinically useful agents for the treatment of asthma [92].

\subsection{Tachykinins}

Tachykinin peptides are one of the largest family of neuropeptides present from invertebrates to mammals. They are derived from the posttranslational processing of three preprotachykinin precursors: preprotachykinin A, consisting of substance $\mathrm{P}(\mathrm{SP})$, neurokinin A (NKA), neuropeptide K (NPK) and neuropeptide- $\gamma$ (NP $\gamma$ ); preprotachykinin B-neurokinin B (NKB) [96]; and several related peptides in different species, such as hemokinin-1 (HK-1) in mice, endokinin-1 and -2 (EK-1 and EK-2) in rabbits, and endokinins A-D (EKA, EKB, EKC and EKD) in humans [97]. All tachykinins share common C-terminal sequence and affinity to all tachykinin receptor with a various potency (for details, see Table 2). A case-control study in the Canary Islands revealed a significant association between tachykinin gene polymorphism and asthma [98].

Table 2. Alignment of the amino acid sequence of the mammalian tachykinin and their preferences for tachykinin receptors [99]. The role of NKA receptors in asthma.

\begin{tabular}{|c|c|c|c|}
\hline Peptide (Sequence) & Affinity [99] & Activation & KA Receptors \\
\hline SP (RPKPQQFFGLM) & NK1 > NK2 >> NK3 & \multirow{7}{*}{$\begin{array}{c}\text { NK1 } \\
\uparrow \text { inflammatory cells } \\
\text { recruitment }[100,101]\end{array}$} & \multirow{7}{*}{$\begin{array}{c}\text { NK1, NK2, NK3 } \\
\text { 个airway smooth muscle } \\
\text { constriction }[102,103]\end{array}$} \\
\hline NKA (HKTDSFVGLM) & NK2 > NK $3>$ NK1 & & \\
\hline NKB (DMHDFFVGLM) & $\mathrm{NK} 3>\mathrm{NK} 2$ & & \\
\hline HK1 (RSRTRQFYGLM) & $\mathrm{NK} 1>>\mathrm{NK} 2>>\mathrm{NK} 3$ & & \\
\hline Endokinin (A/B GKASQFFGLM) & $\mathrm{NK} 1>\mathrm{NK} 2>>\mathrm{NK} 3$ & & \\
\hline Endokinin C (KKAYQLEHTFQGLL) & NK3 & & \\
\hline Endokinin D (VGAYQLEHTFQGLL) & NK3 & & \\
\hline
\end{tabular}

There are two sources of tachykinins in the airways: neural and non-neural. The main sources of SP and NKA are considered to be not only sensitive to capsaicin primary afferent neurons $[104,105]$ but also excitatory nonadrenergic noncholinergic (e-NANC) nerves [106,107] (Figure 2). Substance P and NKA were also detected in neurons within the epithelium, around blood vessels and submucosal glands and within the bronchial smooth muscle layer $[105,108]$. Non-neuronal sources of tachykinins in the airways were reported in epithelium (SP) [109] and airway smooth muscle [110]. Moreover, SP was shown to be produced by eosinophils, monocytes, macrophages, lymphocytes and dendritic cells [111-114]. NKB was not detected in the airways so far [115]. Classical tachykinins (SP, NKA and NKB) possess a wide distribution in the central and peripheral nervous system, which is one of the major sources of these peptides [116]; however, HK-1 is predominantly expressed in non-neuronal tissues as indicated by Page and coworkers [99] in the lung, bone marrow, thymus, skeletal muscle and lymph node, as well as together with SP by various inflammatory and immune cells, such as $\mathrm{T}$ and B lymphocytes, macrophages and dendritic cells $[117,118]$. Tachykinins are involved in a cough reflex and in the inflammatory response in the lungs, as they were shown to be important mediators of the neurogenic inflammation in asthma, allergic rhinitis and chronic bronchitis [119]. Substance $\mathrm{P}$ for instance acts directly on airway goblet cells, as well as submucosal glands inducing mucus secretion $[120,121]$. SP and HK-1 generated from macrophages, bronchial cells and mast cells cause degranulation of human mast cells via MRGPRX2, Mas-related G protein-coupled receptor- $\mathrm{X} 2$, which is upregulated in the lung mast cells and serum of asthmatic patients [122]. SP has been shown to enhance TNF-alpha synthesis and secretion from human mast cells [100]. Endogenous tachykinins have been shown to also modulate the IL-17-induced neutrophil recruitment in vivo in rat airways. The selective blockade of NK1, in contrast to blockade of NK2 receptors, limits the recruitment of neutrophils in rat airways [101]. There is also strong evidence indicating the role of tachykinins and 
tachykinin receptors NK1 in recruiting eosinophils into the airways after allergen challenge [119]. Although the SP content in the sputum or BAL of asthmatics is elevated compared to healthy controls, it seems to have minor effects on the acute phase of allergic asthma. SP applied intravenously or via inhalation in human subjects was not able to produce bronchoconstriction in contrast to NKA [123], although a role for tachykinins in muscle contraction is indicated by the presence of all NK1, NK2 and NK3 receptors in human airway smooth muscle [102]. However, both peptides SP and NKA have been shown to be involved in the development of airway hyperreactivity (Table 3) [119]. In contrast to SP and NKA — both being "classic tachykinins"-HK-1 had no influence over bronchial hyperreactivity [124]. Application via inhalation of CS-003, a triple tachykinin receptors antagonist, evoked diminished bronchoconstriction after methacholine provocation [103]. On the other hand, there is also a less optimistic study showing that chronic administration of an NK1 receptor antagonist, maropitant, was ineffective in reducing signs of neurogenic airway inflammation, eosinophilia and AHR in an experimental feline model of asthma [125]. The more detailed information on the role of tachykinins in asthma was described in the latest review by Pavon-Romero et al. [5]

\subsection{CGRP}

Although the calcitonin gene-related peptide (CGRP) has been described quite thoroughly in the context of its role in asthma in the article by Pavon-Romeiro et al. [5], it is impossible not to mention it in this review. CGRP is synthesized in the airway epithelium, in neuroepithelial bodies and together with SP in the sensory nerve endings of the vagus $C$-fiber and released into the airway when an allergic stimulus is acted upon (Figure 2) [126,127]. It was established that CGRP is involved in the late asthmatic response, evoking vasodilatation, mucus secretion and edema in the airways [128-130]. Although CGRP has been described to potentiate tracheal muscle contraction in response to capsaicin and an electric field stimulation in vitro [131,132], a more recent study has shown that exogenous CGRP in an allergic mouse model of asthma was able to reduce AHR and eosinophilic inflammation [133]. As it turns out, the role of this peptide in the pathogenesis of asthma is far from clear. A further study showed that the transfer of CGRP-pretreated dendritic cells to in vivo model of allergic asthma reduced airway inflammation, shown as decreased BALF eosinophil influx and increased IL-10 concentration [134].

Table 3. Neuropeptides released by vagus efferents (i-NANC, e-NANC) and retrogradely released by afferents (capsaicin C-fibers) contributing to asthma symptoms. A description of the action of a particular peptide and its receptor involved.

\begin{tabular}{|c|c|c|c|c|}
\hline Peptide (Sequence) & Asthma Suppression & Asthma Promoting & Receptors & References \\
\hline $\begin{array}{c}\text { Vasoactive intestinal polypeptide (VIP) } \\
\text { (HSDAVFTDNYTRLRKQ- } \\
\text { MAVKKYLNSILN) }\end{array}$ & $\begin{array}{l}\text { Mice lacking the VIP } \\
\text { gene exhibited } \\
\text { spontaneous asthma } \\
\text { features including AHR } \\
\text { Bronchodilatation }\end{array}$ & & VAPC2 & $\begin{array}{c}{[95]} \\
{[87,94]}\end{array}$ \\
\hline $\begin{array}{c}\text { Substance P (SP) } \\
\text { (RPKPQQFFGLM) } \\
\\
\text { Neurokinin A (NKA) } \\
\text { (HKTDSFVGLM) } \\
\text { HK-1 } \\
\text { (RSRTRQFYGLM) }\end{array}$ & & $\begin{array}{c}\uparrow \text { mucus secretion } \\
\uparrow \text { development of AHR } \uparrow \\
\text { recruitment of airwayneutrophils, } \\
\uparrow \text { degranulation of mast cells } \\
\uparrow \text { bronchoconstriction } \\
\uparrow \text { development of AHR } \\
\uparrow \text { degranulation of mast cells }\end{array}$ & $\begin{array}{c}\text { NK1 } \\
\text { NK2 } \\
\text { NK-1, MRGPRX2 }\end{array}$ & $\begin{array}{c}{[102,119,123]} \\
{[122]}\end{array}$ \\
\hline $\begin{array}{c}\text { Calcitonin gene-related peptide } \\
\text { (CGRP) } \\
\text { (ACDTATCVTHRLAGLLSRSGGVV } \\
\text { KNNFVPTNVGSKAF) }\end{array}$ & $\begin{array}{c}\downarrow \text { AHR and eosinophilic } \\
\text { inflammation }\end{array}$ & $\begin{array}{c}\uparrow \text { vasodilatation, } \\
\uparrow \text { mucus secretion and edema } \\
\uparrow \text { trachea muscle contractions to } \\
\text { capsaicin and electrical field }\end{array}$ & RAMP 1 & $\begin{array}{c}{[5,128-132]} \\
{[133]}\end{array}$ \\
\hline
\end{tabular}




\section{Adipokines}

\subsection{Adiponectin}

Adiponectin participates in the regulation of energy metabolism at the level of adipose tissue and the liver [135] and sensitizes body cells to insulin [136]. Adiponectin receptors and transport molecules are expressed in the lungs [137-139], where adiponectin has been shown to reduce pulmonary inflammation $[140,141]$. The overall anti-inflammatory action of adiponectin involves the inhibition of NF- $\kappa \mathrm{B}$ activation and production proinflammatory cytokine IL-6 and the induction of the expression of anti-inflammatory IL-10 [142,143].

There are contradictory data about the relationship between adiponectin and asthma in the general human population. It seems that its action depends not only on the sex and age of the participants, but also on their hormonal status (pre- and post-puberty; pre- and post-menopause) and the presence and degree of obesity. Lower levels of adiponectin have been observed in asthmatics [144-149]. In general, low adiponectin levels are associated with a higher incidence of asthma [115], poor lung function [150-153] and increased risk of asthma $[154,155]$. At the same time, higher adiponectin levels seem to play a protective role [156]. In this context, Ding et al. [157] found that, during exacerbations, adiponectin levels significantly decreased, together with an increase of inflammatory markers, such as like IL- 6 and TNF- $\alpha$, indicating that adiponectin may play a protective role in the pathogenesis of asthma.

In contrast, other researchers [158-160] could not find any correlation between adiponectin, asthma and lung function. In animal models of OVA-induced asthma, Nigro et al. [161] found decreased levels of adiponectin. At the same time, in OVA-sensitized mice, continuous administration of exogenous adiponectin alleviated symptoms of the disease (Table 4) [162]. More research data about adiponectin, its mechanisms of action and its role in asthma were recently presented in an excellent review by Otelea et al. [163].

\subsection{Leptin}

Leptin is an energy-regulating adipokine released in response to feeding and inflammation or infection $[164,165]$. It plays an important role not only in energy metabolism but also in learning processes [166]; hormonal changes, fertility, onset of puberty and regulation of bone mass [167]; and immunity [168,169], including inflammatory disorders of the respiratory system. Leptin is expressed by various cell types of the respiratory system including bronchial and alveolar epithelial and smooth muscle cells, macrophages and bronchial submucosa, and, as a consequence, it can be found in BALF [169-172]. Leptin is a pro-inflammatory adipokine and is believed to promote pulmonary inflammation and bronchoconstriction [145].

Most of the studies show that asthmatic subjects have higher leptin levels $[132,144,145$, 151,159,160,173-179]. Higher leptin levels are believed to be associated with asthma severity [180], lower lung function [176,181] and airway hyperreactivity [151]. Leptin levels may be an indicator of asthma control, as its levels rise during exacerbations in adults [182,183]. Moreover, a high leptin level increases the risk of developing asthma [184,185]. Some reports failed to find any association between leptin levels and asthma, its incidence and severity [186-191]. One has to keep in mind that leptin takes part in the pathophysiology of both asthma and obesity and that outcomes of these diseases may overlap, especially in the context of lung function [156,192-194].

The pro-inflammatory effect of leptin has been proven in animal models by Shore et al. [195,196], Lu et al. [197] and Johnston et al. [198], who found that leptin administration enhances airway inflammation. As it has been presented by Shore et al. [196], leptin levels are not only increased in asthma, but leptin itself increases airway hyperreactivity and pro-inflammatory cytokines levels in BALF when administered during sensitization in the OVA allergic asthma model in mice [196]. This suggests that leptin is released in response to inflammation and that leptin itself enhances inflammation $[168,195,196,199]$. 


\subsection{Resistin and Resistin-like Molecule Family (RELM) Proteins}

Resistin is a member of the resistin-like molecule family (RELM) and was previously known as "found in inflammatory zone". It is secreted by the adipose tissue, and its levels are increased in diet-induced and genetic forms of obesity [200].

Resistin is associated with inflammatory diseases [201], including those of the lungs [202, 203]. It is expressed in airway epithelial cells and other cells of the respiratory system [204], where it increases the expression of various mucins [205]. In general, this peptide shows pro-inflammatory activity; when administered to macrophages, resistin induces the release of pro-inflammatory cytokines, including TNF- $\alpha$ [206], which in turn enhances the release of resistin [207]. Its pro-inflammatory action occurs mostly via various signaling pathways, including NFKB [206]. It seems to act in contrast to adiponectin, which was reported to inhibit the effects of resistin [208]. The role of resistin in immunity and inflammatory diseases has been summarized in detail elsewhere [204,209,210]. RELMs are believed to display inflammation-regulating, chemokine and growth-factor properties [204] and are involved in propagation of oxidative stress [211]. While RELM $\alpha$ seems to have an important role in inflammation and airway remodeling in rodents [212-217], and its overexpression seems to protect from development of asthma symptoms in mice [216], the influence of RELM $\beta$ on asthma outcomes is ambiguous [203,218]. Pine et al. [219] sum up findings on the role of RELM $\alpha / \beta$ and resistin in signaling and inflammatory disorders, showing differences between these peptides. Together with Fan et al. [220], they point to slightly different properties of members of the RELM family; their actions seem to vary between rodents and humans, as well as between asthma models.

Resistin levels are higher during asthma exacerbations, as compared to healthy controls, but not during their resolution or follow-up [183]. Additionally, Al Mutaivi et al. [221] observed higher resistin levels in asthmatics, together with an inverse correlation of its concentration with lung function, as did Ballantyne et al. [222], Vezir et al. [223] and LaRochelle et al. [202], who found a link between plasma resistin concentrations and asthma severity. As a consequence, resistin could be a predictor of asthma risk and control. Fang et al. [214,215] and Grainge et al. [224] observed higher expression of RELM $\beta$ in asthmatic humans, which correlated inversely with lung function and positively with mucin production. RELMs and resistin may be involved in airway remodeling and asthma progression [213]. In contrast, Kim et al. [189] found lower resistin levels in asthmatic minors compared to healthy ones and pointed to resistin levels as negative predictors of asthma. As for other adipokines, differences between adults and children might be due to a different hormonal status of both groups also at the level of adipokines. Once again, as is the case of all adipokines, the level of the respective peptide is not as important as the ratios between all of them (Figure 3) [135]. Another interesting resistin issue was described by Leivo-Korpela et al. [180], who found no difference in resistin levels between non-obese female asthmatics and a matched control group after adjusting for BMI. However, higher resistin concentrations predicted a favorable response to inhaled corticosteroids.

Table 4. Obesity-related peptides involved in mediating asthma symptoms. A description of the action of a particular peptide and the receptors through which it acts.

\begin{tabular}{ccccc}
\hline Peptide & Asthma Suppression & Asthma Promoting & Receptors & References \\
\hline Adiponectin & $\begin{array}{c}\text { Reduces airway } \\
\text { inflammation }\end{array}$ & T-cadherin & {$[140,141,147]$} \\
\hline Leptin & & $\begin{array}{c}\text { Promotes airway } \\
\text { inflammation and } \\
\text { bronchoconstriction }\end{array}$ & Ob-R & {$[145,169,194]$} \\
Resistin & $\begin{array}{c}\text { Promotes airway } \\
\text { inflammation and } \\
\text { airway remodeling }\end{array}$ & Not known & {$[204,209,210]$} \\
\hline \multirow{2}{*}{ Ghrelin } & $\begin{array}{c}\text { Reduces airway } \\
\text { inflammation and } \\
\text { airway hyperreactivity }\end{array}$ & GHS-R & {$[225-227]$} \\
\hline
\end{tabular}


Pro-inflammatory peptides in asthma

$$
\begin{gathered}
\uparrow \text { Leptin* } \\
\uparrow \text { Resistin } \\
\text { During exacerbations } \\
\uparrow \text { Leptin } \\
\uparrow \text { Resistin }
\end{gathered}
$$

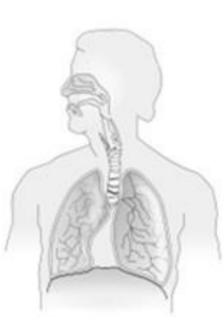

Leptin:

$\uparrow$ Airway hyperreactivity

$\uparrow$ Pro-inflammatory cytokines

$\uparrow$ Cellularinflux

Resistin:

$\uparrow$ Pro-inflammatory cytokines

$\uparrow$ Airway remodelling

$\uparrow$ Mucus secretion

\section{Adiponectin:}

$\downarrow$ Airway hyperreactivity

$\downarrow$ Pro-inflammatory cytokines

$\uparrow$ Anti-inflammatory cytokines

$\downarrow$ Cellularinflux

Ghrelin:

$\downarrow$ Airway hyperreactivity

$\downarrow$ Pro-inflammatory cytokines

$\uparrow$ Anti-inflammatory cytokines

$\downarrow$ Airway remodelling

Figure 3. Influence of pro- and anti-inflammatory obesity-related peptides on the main features of asthma. One must keep in mind that it is not the concentration of the respective peptide alone that counts but also the ratios between them [135]. * is present in the figure body.

\section{Stomach Peptide Ghrelin}

Gastrin-associated ghrelin is a peptide involved in the regulation of energy metabolism and plays a possible role in the pathogenesis of asthma. It is released from the stomach in response to hunger and, thus, regulates the food intake [228]. As is the case with adipokines, its levels are disturbed in obesity and metabolic disorders. Ghrelin is expressed in many tissues, including lungs and bronchial epithelial cells [229,230], and its receptors have been found in lung parenchyma [231]. It is believed to have antimicrobial and anti-inflammatory properties [232,233], mostly by downregulation of expression of proinflammatory cytokines and upregulation of the anti-inflammatory ones both in vitro and in vivo [232,234-236]. Moreover, ghrelin attenuates neutrophil migration [225]; decreases fibroblast activity, preventing organ fibrosis [237]; and decreases collagen production [238]. Its cytoprotective properties rely mostly on the suppression of endoplasmic reticulumrelated stress [239].

The anti-inflammatory action of ghrelin occurs mostly via the inhibition of the NFkB pathway [240,241], and not by scavenging intracellular ROS [226] even if ghrelin has antioxidant properties $[228,233,242]$. The influence of ghrelin on oxidative stress inflammation and its role in immunity has been summarized by Wang et al. [243], Baatar et al. [225] and Jafari et al. [244], among others, who detailed the characteristics of the cytokines involved in the anti-inflammatory action of ghrelin.

Up to now, there is only one report on the influence of ghrelin on asthma symptoms in animals. In OVA-sensitized mice, ghrelin administration decreased almost all asthmarelated features, including cellular influx into the airways, pro-inflammatory cytokine levels in BALF, thickening of the airway epithelium and airway hyperreactivity [227]. As 
for humans, observations regarding ghrelin levels in asthma and its potential role are conflicting. Matsumoto et al. [147], Tsaroucha et al. [245] and Yuksel et al. [246] found lower ghrelin levels in asthmatics as compared to controls, but no correlation between ghrelin levels and asthma severity. Moreover, lower ghrelin levels have been found during exacerbations than during stable periods in the same subjects [245]. In addition, Matsuda et al. [247] described how ghrelin levels negatively correlated with IgE production, leading to the conclusion that ghrelin might inhibit directly or indirectly IgE synthesis. In contrast to the abovementioned research, Al-Ayed et al. [248] found higher ghrelin levels in asthmatic children than in non-asthmatic ones. Moreover, subjects with uncontrolled asthma had higher ghrelin than patients with well-controlled disease. Higher ghrelin levels were also found in asthmatic adults by Toru et al. [249].

In chronic respiratory infections in undernourished patients, Kodama et al. [250] found that ghrelin administration suppressed airway inflammation, decreased accumulation of neutrophils in the lung and led to weight gain. Miki et al. [251] described an increased respiratory strength and better respiratory outcomes of COPD patients after ghrelin treatment, thus indicating a possible therapeutic role of ghrelin in other obstructive and inflammatory diseases of the respiratory system, such as asthma.

\section{Antimicrobial Peptides (AMPs)}

Another group of peptides employed by the host to discard microorganisms are antimicrobial peptides, presenting diverse biological functions. One of them is LL-37, a 37 amino acid cationic peptide belonging to the cathelicidin family of antimicrobial peptides $[252,253]$. The most important factors that stimulate the production of LL-37 are pathogens (particles of bacterial origin), skin damage and vitamin D3. They stimulate LL-37 expression in epithelium and inflammatory cells [254], where, apart from antimicrobial activity, it is involved in wound healing, angiogenesis, cell apoptosis and immunomodulation [255]. The impact of LL-37 on allergic asthma seems to be rather proinflammatory (Table 5), since it is chemotactic to eosinophils, neutrophils and mast cells and deteriorates airway inflammation and AHR in a mouse model of allergic asthma [255]. What is more, LL-37 has been displayed to induce eosinophilic release of cysteinyl leukotrienes, which are potent bronchoconstrictors, also exacerbating inflammation [256]. It is not without reason that bacterial infections, which induce the release of LL-37, account for approximately 50\% of asthma exacerbations [257].

Table 5. Description of the effect of antimicrobial peptides on asthma pathology.

\begin{tabular}{cccc}
\hline Peptide & Asthma Suppression & Asthma Promoting & References \\
\hline LL-37 & $\begin{array}{c}\text { Proinflammatory and } \\
\text { exacerbates inflammation } \\
\text { and AHR }\end{array}$ & {$[254-256]$} \\
\hline $\begin{array}{c}\beta \text {-defensin 1 } \\
\text { (hBD-1) }\end{array}$ & $\begin{array}{c}\text { Promotes airway } \\
\text { inflammation; } \\
\text { chemoattractant for } \\
\text { immune cells }\end{array}$ & {$[254,258]$} \\
\hline $\begin{array}{c}\beta \text {-defensin 2 } \\
\text { (hBD-2) }\end{array}$ & $\begin{array}{c}\text { Prevents airway } \\
\text { inflammation and AHR }\end{array}$ & {$[259,260]$} \\
\hline
\end{tabular}

The largest group of AMPs produced by mammals are defensins, first discovered in human neutrophils. In humans, $\alpha$ - and $\beta$-defensins are found in neutrophil granules, macrophages, NK cells, skin, body fluids and respiratory mucosa, among others [252]. Human $\beta$-defensin 1 (hBD-1) is expressed constitutively in the respiratory tract, while $\beta$-defensin 2 (hBD-2), hBD-3 and hBD-4 are induced by infectious agents, tissue damage or proinflammatory cytokines [254]. Defensins are chemoattractants for immune cells; they also activate dendritic cells and mast cells to degranulate, resulting in the release of histamine and other inflammatory and allergic mediators [254]. Defensins, which act as 
inflammatory mediators, appear to be involved in the pathogenesis of asthma. Associations between asthma diagnosis and genetic variation in human hBD-1 encoding gene have been suggested [258]. Borchers et al. [259] hypothesized that variants in the gene encoding hBD-2 may be a risk factor for the development of asthma if they result in insufficient production of hBD-2. As confirmation, multiple genetic variants of this gene have been identified associated with asthma and allergy in the pediatric population. Additionally, it was confirmed in a mouse model of asthma that the application of exogenous hBD-2 prevents key symptoms of asthma, such as BALF inflammatory cell influx, cytokine production and AHR $[259,260]$. This suggests that hBD-2 has a mitigating effect on asthma symptoms.

\section{Conclusions}

The plethora of described peptides involved in the regulation of asthma-specific symptoms suggests many opportunities to explore new therapeutic pathways for this complex disease. Their advantage is that they are natural endogenous peptides present in the human body. However, sometimes the multiplicity of receptors and bodily functions they can affect prevents their use as potential therapeutics. The solution may be the search for new selective agonists or antagonists. Some of the studies described in the review based on animal models so far have shown beneficial effects in reducing asthma symptoms by activating nociception NOP1, bombesin BRS-3 and somatostatin SST4 receptors, or blocking the NPY-Y1 receptor. Peptides related to energy, glucose metabolism and turnover play an important role in the pathophysiology of obesity-related asthma. They can enhance (e.g., leptin or resistin) or alleviate (e.g., adiponectin and ghrelin) various features of asthma, acting either pro- or anti-inflammatory, respectively. Despite the strong interest in peptides, further studies exploring their true role in asthma pathology are needed. Sometimes this role is still unclear, and it is not uncommon for opposite data to be published.

Author Contributions: Conceptualization, K.K. and D.Z.; formal analysis, D.Z., M.J., P.W. and K.K.; writing, K.K., D.Z. and M.J., P.W.; writing-review and editing, K.K. and D.Z.; visualization, K.K., D.Z., M.J. and P.W.; supervision, K.K. All authors have read and agreed to the published version of the manuscript.

Funding: This research received no external funding.

Institutional Review Board Statement: Not applicable.

Informed Consent Statement: Not applicable.

Conflicts of Interest: The authors declare no conflict of interest.

\section{References}

1. Enilari, O.; Sinha, S. The global impact of asthma in adult populations. Ann. Glob. Health 2019, 85, 2. [CrossRef]

2. GINA 2021. Global Initiative for Asthma. Global Strategy for Asthma Management and Prevention. 2021. Available online: https:/ / ginasthma.org/gina-reports/ (accessed on 2 June 2021).

3. Barnes, P.J. The cytokine network in asthma and chronic obstructive pulmonary disease. J. Clin. Investig. 2008, 118, $3546-3556$. [CrossRef]

4. Kaczyńska, K.; Zając, D.; Wojciechowski, P.; Kogut, E.; Szereda-Przestaszewska, M. Neuropeptides and breathing in health and disease. Pulm. Pharmacol. Ther. 2018, 48, 217-224. [CrossRef]

5. Pavón-Romero, G.F.; Serrano-Pérez, N.H.; García-Sánchez, L.; Ramírez-Jiménez, F.; Terán, L.M. Neuroimmune Pathophysiology in Asthma. Front. Cell Dev. Biol. 2021, 9, 663535. [CrossRef]

6. Van Lommel, A. Pulmonary neuroendocrine cells (PNEC) and neuroepithelial bodies (NEB): Chemoreceptors and regulators of lung development. Paediatr. Respir. Rev. 2001, 2, 171-176. [CrossRef]

7. Underner, M.; Millet, C.; Charrière, V.; Dore, P.; Meurice, J.C.; Patte, F. Neuropeptides and respiratory diseases: Prospects in the treatment of asthma. Rev. Pneumol. Clin. 1989, 45, 144-151. [PubMed]

8. Barnes, P.J. Neuropeptides as modulators of airway function. Agents Actions Suppl. 1990, 31, 175-196.

9. Saaresranta, T.; Polo, O. Hormones and breathing. Chest 2002, 122, 2165-2182. [CrossRef] [PubMed]

10. Russjan, E.; Kaczyńska, K. Beneficial Effects of Neurotensin in Murine Model of Hapten-Induced Asthma. Int. J. Mol. Sci. 2019, 20, 5025. [CrossRef] 
11. Oda, N.; Miyahara, N.; Taniguchi, A.; Morichika, D.; Senoo, S.; Fujii, U.; Itano, J.; Gion, Y.; Kiura, K.; Kanehiro, A.; et al. Requirement for neuropeptide $\mathrm{Y}$ in the development of type 2 responses and allergen-induced airway hyperresponsiveness and inflammation. Am. J. Physiol. Lung Cell. Mol. Physiol. 2019, 316, L407-L417. [CrossRef] [PubMed]

12. Hersoug, L.G.; Linneberg, A. The link between the epidemics of obesity and allergic diseases: Does obesity induce decreased immune tolerance? Allergy 2007, 62, 1205-1213. [CrossRef]

13. Garcia, P.; Sood, A. Adiponectin in Pulmonary Disease and Critically Ill Patients. Curr. Med. Chem. 2012, 19, 5493-5500. [CrossRef] [PubMed]

14. Gehlert, D.R. Introduction to the reviews on neuropeptide Y. Neuropeptides 2004, 38, 135-140. [CrossRef]

15. Kuo, L.E.; Kitlinska, J.B.; Tilan, J.U.; Li, L.; Baker, S.B.; Johnson, M.D.; Lee, E.W.; Burnett, M.S.; Fricke, S.T.; Kvetnansky, R.; et al. Neuropeptide $\mathrm{Y}$ acts directly in the periphery on fat tissue and mediates stress-induced obesity and metabolic syndrome. Nat. Med. 2007, 13, 803-811. [CrossRef] [PubMed]

16. Buttari, B.; Profumo, E.; Domenici, G.; Tagliani, A.; Ippoliti, F.; Bonini, S.; Businaro, R.; Elenkov, I.; Riganò, R. Neuropeptide Y induces potent migration of human immature dendritic cells and promotes a Th2 polarization. FASEB J. 2014, 28, 3038-3049. [CrossRef] [PubMed]

17. Macia, L.; Rao, P.T.; Wheway, J.; Sierro, F.; Mackay, F.; Herzog, H. Y1 signaling has a critical role in allergic airway inflammation. Immun. Cell Biol. 2011, 89, 882-888. [CrossRef]

18. Makinde, T.O.; Steininger, R.; Agrawal, D.K. NPY and NPY receptors in airway structural and inflammatory cells in allergic asthma. Exp. Mol. Pathol. 2013, 94, 45-50. [CrossRef]

19. Cadieux, A.; Benchekroun, M.T.; St-Pierre, S.; Fournier, A. Bronchoconstrictor action of neuropeptide Y (NPY) in isolated guinea pig airways. Neuropeptides 1989, 13, 215-219. [CrossRef]

20. Li, S.; Koziol-White, C.; Jude, J.; Jiang, M.; Zhao, H.; Cao, G.; Yoo, E.; Jester, W.; Morley, M.P.; Zhou, S.; et al. Epithelium-generated neuropeptide $Y$ induces smooth muscle contraction to promote airway hyperresponsiveness. J. Clin. Investig. 2016, 126, 1978-1982. [CrossRef] [PubMed]

21. Iyer, M.R.; Kunos, G. Therapeutic approaches targeting the neurotensin receptors. Expert Opin. Ther. Pat. 2021, 31, 361-386. [CrossRef]

22. Vacca, P.; Carbone, R.; Monselise, A.; Grosso, M.; Bottino, G. Neurotensin pulmonary metabolism in normal and asthmatic subjects. Eur. Rev. Med. Pharmacol. Sci. 2003, 7, 75-80. [PubMed]

23. Aas, P.; Helle, K.B. Neurotensin receptors in the rat bronchi. Regul. Pept. 1982, 3, 405-413. [CrossRef]

24. Djokic, T.D.; Dusser, D.J.; Borson, D.B.; Nadel, J.A. Neutral endopeptidase modulates neurotensin-induced airway contraction. J. Appl. Physiol. 1989, 66, 2338-2343. [CrossRef] [PubMed]

25. Martin, C.A.; Gully, D.; Naline, E.; Advenier, C. Neurotensin modulates cholinergic and noncholinergic neurotransmission in guinea-pig main bronchi in vitro. Neuropeptides 1994, 26, 159-166. [CrossRef]

26. Russjan, E.; Andrzejewski, K.; Sulejczak, D.; Kleczkowska, P.; Kaczyńska, K. Endomorphin-2- and Neurotensin- Based Chimeric Peptide Attenuates Airway Inflammation in Mouse Model of Nonallergic Asthma. Int. J. Mol. Sci. 2019, 20, 5935. [CrossRef] [PubMed]

27. Russjan, E.; Zając, D.; Sulejczak, D.; Kleczkowska, P.; Kaczyńska, K. Contribution of opioid and neurotensin receptors in the anti-inflammatory activity of PK20 hybrid compound in murine airways. Clin. Exp. Pharmacol. Physiol. 2021, 48, 1162-1170. [CrossRef]

28. Reinscheid, R.K. Neuropeptide S: Anatomy, pharmacology, genetics and physiological functions. Results Probl. Cell Differ. 2008, 46, 145-158. [CrossRef]

29. Kushikata, T.; Hirota, K.; Saito, J.; Takekawa, D. Roles of Neuropeptide S in Anesthesia, Analgesia, and Sleep. Pharmaceuticals 2021, 14, 483. [CrossRef]

30. Castro-Giner, F.; de Cid, R.; Gonzalez, J.R.; Jarvis, D.; Heinrich, J.; Janson, C.; Omenaas, E.R.; Matheson, M.C.; Pin, I.; Anto, J.M.; et al. Positionally cloned genes and age-specific effects in asthma and atopy: An international population-based cohort study (ECRHS). Thorax 2010, 65, 124-131. [CrossRef]

31. Acevedo, N.; Ezer, S.; Kebede Merid, S.; Gaertner, V.D.; Söderhäll, C.; D'Amato, M.; Kabesch, M.; Melén, E.; Kere, J.; Pulkkinen, V. Neuropeptide S (NPS) variants modify the signaling and risk effects of NPS Receptor 1 (NPSR1) variants in asthma. PLoS ONE 2017, 12, e0176568. [CrossRef]

32. Laitinen, T.; Polvi, A.; Rydman, P.; Vendelin, J.; Pulkkinen, V.; Salmikangas, P.; Mäkelä, S.; Rehn, M.; Pirskanen, A.; Rautanen, A.; et al. Characterization of a common susceptibility locus for asthma-related traits. Science 2004, 304, 300-304. [CrossRef] [PubMed]

33. Vendelin, J.; Pulkkinen, V.; Rehn, M.; Pirskanen, A.; Räisänen-Sokolowski, A.; Laitinen, A.; Laitinen, L.A.; Kere, J.; Laitinen, T. Characterization of GPRA, a novel G protein-coupled receptor related to asthma. Am. J. Respir. Cell. Mol. Biol. 2005, 33, $262-270$. [CrossRef]

34. Hamsten, C.; Häggmark, A.; Grundström, J.; Mikus, M.; Lindskog, C.; Konradsen, J.R.; Eklund, A.; Pershagen, G.; Wickman, M.; Grunewald, J.; et al. Protein profiles of CCL5, HPGDS, and NPSR1 in plasma reveal association with childhood asthma. Allergy 2016, 71, 1357-1361. [CrossRef] [PubMed]

35. Zhu, H.; Perkins, C.; Mingler, M.K.; Finkelman, F.D.; Rothenberg, M.E. The role of neuropeptide S and neuropeptide S receptor 1 in regulation of respiratory function in mice. Peptides 2011, 32, 818-825. [CrossRef] [PubMed] 
36. Ilmarinen, P.; James, A.; Moilanen, E.; Pulkkinen, V.; Daham, K.; Saarelainen, S.; Laitinen, T.; Dahlén, S.E.; Kere, J.; Dahlén, B.; et al. Enhanced expression of neuropeptide S (NPS) receptor in eosinophils from severe asthmatics and subjects with total IgE above 100IU/ml. Peptides 2014, 51, 100-109. [CrossRef] [PubMed]

37. Wtorek, K.; Janecka, A. Potential of Nociceptin/Orphanin FQ Peptide Analogs for Drug Development. Chem. Biodivers. 2021, 18, e2000871. [CrossRef]

38. D'Agostino, B.; Sgambato, M.; Esposito, R.; Spaziano, G. N/OFQ-NOP System and Airways. Handb. Exp. Pharmacol. 2019, 254, 313-322. [CrossRef]

39. Shah, S.; Page, C.P.; Spina, D. Nociceptin inhibits non-adrenergic non-cholinergic contraction in guinea-pig airway. Br. J. Pharmacol. 1998, 125, 510-516. [CrossRef] [PubMed]

40. D'Agostino, B.; Orlotti, D.; Calò, G.; Sullo, N.; Russo, M.; Guerrini, R.; De Nardo, M.; Mazzeo, F.; Candeletti, S.; Rossi, F. Nociceptin modulates bronchoconstriction induced by sensory nerve activation in mouse lung. Am. J. Respir. Cell. Mol. Biol. 2010, 42, 250-254. [CrossRef]

41. McLeod, R.L.; Bolser, D.C.; Jia, Y.; Parra, L.E.; Mutter, J.C.; Wang, X.; Tulshian, D.B.; Egan, R.W.; Hey, J.A. Antitussive effect of nociceptin/orphanin FQ in experimental cough models. Pulm. Pharmacol. Ther. 2002, 15, 213-216. [CrossRef]

42. Singh, S.R.; Sullo, N.; D'Agostino, B.; Brightling, C.E.; Lambert, D.G. The effects of nociceptin peptide (N/OFQ)-receptor (NOP) system activation in the airways. Peptides 2013, 39, 36-46. [CrossRef]

43. Singh, S.R.; Sullo, N.; Matteis, M.; Spaziano, G.; McDonald, J.; Saunders, R.; Woodman, L.; Urbanek, K.; De Angelis, A.; De Palma, R.; et al. Nociceptin/orphanin FQ (N/OFQ) modulates immunopathology and airway hyperresponsiveness representing a novel target for the treatment of asthma. Br. J. Pharmacol. 2016, 173, 1286-1301. [CrossRef] [PubMed]

44. Sullo, N.; Roviezzo, F.; Matteis, M.; Ianaro, A.; Calò, G.; Guerrini, R.; De Gruttola, L.; Spaziano, G.; Cirino, G.; Rossi, F.; et al. Nociceptin/orphanin FQ receptor activation decreases the airway hyperresponsiveness induced by allergen in sensitized mice. Am. J. Physiol. Lung Cell. Mol. Physiol. 2013, 304, L657-L664. [CrossRef] [PubMed]

45. Spaziano, G.; Sorrentino, R.; Matteis, M.; Malgieri, G.; Sgambato, M.; Russo, T.P.; Terlizzi, M.; Roviezzo, F.; Rossi, F.; Pinto, A.; et al. Nociceptin reduces the inflammatory immune microenvironment in a conventional murine model of airway hyperresponsiveness. Clin. Exp. Allergy 2017, 47, 208-216. [CrossRef] [PubMed]

46. Tartaglione, G.; Spaziano, G.; Sgambato, M.; Russo, T.P.; Liparulo, A.; Esposito, R.; Mirra, S.; Filosa, R.; Roviezzo, F.; Polverino, F.; et al. Nociceptin/Orphanin Fq in inflammation and remodeling of the small airways in experimental model of airway hyperresponsiveness. Physiol. Rep. 2018, 6, e13906. [CrossRef]

47. Jensen, R.T.; Battey, J.F.; Spindel, E.R.; Benya, R.V. International Union of Pharmacology. LXVIII. Mammalian bombesin receptors: Nomenclature, distribution, pharmacology, signaling, and functions in normal and disease states. Pharmacol. Rev. 2008, 60, 1-42. [CrossRef]

48. Majumdar, I.D.; Weber, H.C. Biology of mammalian bombesin-like peptides and their receptors. Curr. Opin. Endocrinol. Diabetes Obes. 2011, 18, 68-74. [CrossRef] [PubMed]

49. Emanuel, R.L.; Torday, J.S.; Mu, Q.; Asokananthan, N.; Sikorski, K.A.; Sunday, M.E. Bombesin-like peptides and receptors in normal fetal baboon lung: Roles in lung growth and maturation. Am. J. Physiol. 1999, 277, L1003-L1017. [CrossRef]

50. Kane, M.A.; Toi-Scott, M.; Johnson, G.L.; Kelley, K.K.; Boose, D.; Escobedo-Morse, A. Bombesin-like peptide receptors in human bronchial epithelial cells. Peptides 1996, 17, 111-118. [CrossRef]

51. Shan, L.; Emanuel, R.L.; Dewald, D.; Torday, J.S.; Asokanathan, N.; Wada, K.; Wada, E.; Sunday, M.E. Bombesin-like peptide receptor gene expression, regulation, and function in fetal murine lung. Am. J. Physiol. Lung Cell. Mol. Physiol. 2004, 286, L165-L173. [CrossRef]

52. Lach, E.; Haddad, E.B.; Gies, J.P. Contractile effect of bombesin on guinea pig lung in vitro: Involvement of gastrin-releasing peptide-preferring receptors. Am. J. Physiol. 1993, 264, L80-L86. [CrossRef] [PubMed]

53. Zhou, S.; Potts, E.N.; Cuttitta, F.; Foster, W.M.; Sunday, M.E. Gastrin-releasing peptide blockade as a broad-spectrum antiinflammatory therapy for asthma. Proc. Natl. Acad. Sci. USA 2011, 108, 2100-2105. [CrossRef]

54. Subramaniam, M.; Sugiyama, K.; Coy, D.H.; Kong, Y.; Miller, Y.E.; Weller, P.F.; Wada, K.; Wada, E.; Sunday, M.E. Bombesin-like peptides and mast cell responses: Relevance to bronchopulmonary dysplasia? Am. J. Respir. Crit. Care Med. 2003, 168, 601-611. [CrossRef] [PubMed]

55. Oliveira, P.G.; Brenol, C.V.; Edelweiss, M.I.; Brenol, J.C.; Petronilho, F.; Roesler, R.; Dal-Pizzol, F.; Schwartsmann, G.; Xavier, R.M. Effects of an antagonist of the bombesin/gastrin-releasing peptide receptor on complete Freund's adjuvant-induced arthritis in rats. Peptides 2008, 29, 1726-1731. [CrossRef] [PubMed]

56. Dal-Pizzol, F.; Di Leone, L.P.; Ritter, C.; Martins, M.R.; Reinke, A.; Pens Gelain, D.; Zanotto-Filho, A.; de Souza, L.F.; Andrades, M.; Barbeiro, D.F.; et al. Gastrin-releasing peptide receptor antagonist effects on an animal model of sepsis. Am. J. Respir. Crit. Care Med. 2006, 173, 84-90. [CrossRef]

57. Petronilho, F.; Roesler, R.; Schwartsmann, G.; Dal Pizzol, F. Gastrin-releasing peptide receptor as a molecular target for inflammatory diseases. Inflamm. Allergy Drug Targets 2007, 6, 197-200. [PubMed]

58. Sunday, M.E.; Yoder, B.A.; Cuttitta, F.; Haley, K.J.; Emanuel, R.L. Bombesin-like peptide mediates lung injury in a baboon model of bronchopulmonary dysplasia. J. Clin. Investig. 1998, 102, 584-594. [CrossRef] [PubMed]

59. Qin, X.Q.; Qu, X. Extraintestinal roles of bombesin-like peptides and their receptors: Lung. Curr. Opin. Endocrinol. Diabetes Obes. 2013, 20, 22-26. [CrossRef] 
60. Li, M.; Liang, P.; Liu, D.; Yuan, F.; Chen, G.C.; Zhang, L.; Liu, Y.; Liu, H. Bombesin Receptor Subtype-3 in Human Diseases. Arch. Med. Res. 2019, 50, 463-467. [CrossRef] [PubMed]

61. Wang, Y.; Zhang, M.; Tan, Y.; Xiang, Y.; Liu, H.; Qu, F.; Qin, L.; Qin, X. BRS-3 activation transforms the effect of human bronchial epithelial cells from PGE2 mediated inhibition to TGF-beta1 dependent promotion on proliferation and collagen synthesis of lung fibroblasts. Cell. Biol. Int. 2007, 31, 1495-1500. [CrossRef] [PubMed]

62. Liu, H.; Peng, L.; Liu, C.; Tan, Y.; Xiang, Y.; Qu, X.; Weber, H.C.; Dai, M.; Qin, X. Activation of Bombesin Receptor Subtype-3 Promotes Antigen-Presenting Action in Human Bronchial Epithelial Cells. Int. Arch. Allergy Immunol. 2018, 175, 53-60. [CrossRef] [PubMed]

63. Gamse, R.; Leeman, S.E.; Holzer, P.; Lembeck, F. Differential effects of capsaicin on the content of somatostatin, substance P, and neurotensin in the nervous system of the rat. Naunyn Schmiedebergs Arch. Pharmacol. 1981, 317, 140-148. [CrossRef] [PubMed]

64. Patel, Y.C.; Greenwood, M.T.; Panetta, R.; Demchyshyn, L.; Niznik, H.; Srikant, C.B. The somatostatin receptor family. Life Sci. 1995, 57, 1249-1265. [CrossRef] [PubMed]

65. ten Bokum, A.M.; Hofland, L.J.; van Hagen, P.M. Somatostatin and somatostatin receptors in the immune system: A review. Eur. Cytokine Netw. 2000, 11, 161-176. [PubMed]

66. Hoyer, D.; Bell, G.I.; Berelowitz, M.; Epelbaum, J.; Feniuk, W.; Humphrey, P.P.; O'Carroll, A.M.; Patel, Y.C.; Schonbrunn, A.; Taylor, J.E.; et al. Classification and nomenclature of somatostatin receptors. Trends Pharmacol. Sci. 1995, 16, 86-88. [CrossRef]

67. Reisine, T.; Bell, G.I. Molecular properties of somatostatin receptors. Neuroscience. 1995, 67, 777-790. [CrossRef]

68. Hofland, L.J.; Visser-Wisselaar, H.A.; Lamberts, S.W. Somatostatin analogs: Clinical application in relation to human somatostatin receptor subtypes. Biochem. Pharmacol. 1995, 50, 287-297. [CrossRef]

69. Borie, R.; Fabre, A.; Prost, F.; Marchal-Somme, J.; Lebtahi, R.; Marchand-Adam, S.; Aubier, M.; Soler, P.; Crestani, B. Activation of somatostatin receptors attenuates pulmonary fibrosis. Thorax 2008, 63, 251-258. [CrossRef]

70. Varecza, Z.; Elekes, K.; László, T.; Perkecz, A.; Pintér, E.; Sándor, Z.; Szolcsányi, J.; Keszthelyi, D.; Szabó, A.; Sándor, K.; et al. Expression of the somatostatin receptor subtype 4 in intact and inflamed pulmonary tissues. J. Histochem. Cytochem. 2009, 57, 1127-1137. [CrossRef]

71. Helyes, Z.; Elekes, K.; Németh, J.; Pozsgai, G.; Sándor, K.; Kereskai, L.; Börzsei, R.; Pintér, E.; Szabó, A.; Szolcsányi, J. Role of transient receptor potential vanilloid 1 receptors in endotoxin-induced airway inflammation in the mouse. Am. J. Physiol. Lung Cell. Mol. Physiol. 2007, 292, L1173-L1181. [CrossRef]

72. Elekes, K.; Helyes, Z.; Kereskai, L.; Sándor, K.; Pintér, E.; Pozsgai, G.; Tékus, V.; Bánvölgyi, A.; Németh, J.; Szuts, T.; et al. Inhibitory effects of synthetic somatostatin receptor subtype 4 agonists on acute and chronic airway inflammation and hyperreactivity in the mouse. Eur. J. Pharmacol. 2008, 578, 313-322. [CrossRef]

73. Helyes, Z.; Pintér, E.; Németh, J.; Kéri, G.; Thán, M.; Oroszi, G.; Horváth, A.; Szolcsányi, J. Anti-inflammatory effect of synthetic somatostatin analogues in the rat. Br. J. Pharmacol. 2001, 134, 1571-1579. [CrossRef]

74. Helyes, Z.; Pinter, E.; Nemeth, J.; Sandor, K.; Elekes, K.; Szabo, A.; Pozsgai, G.; Keszthelyi, D.; Kereskai, L.; Engstrom, M.; et al Effects of the somatostatin receptor subtype 4 selective agonist J-2156 on sensory neuropeptide release and inflammatory reactions in rodents. Br. J. Pharmacol. 2006, 149, 405-415. [CrossRef] [PubMed]

75. Abad, C.; Gomariz, R.P.; Waschek, J.A. Neuropeptide mimetics and antagonists in the treatment of inflammatory disease: Focus on VIP and PACAP. Curr. Top. Med. Chem. 2006, 6, 151-163. [CrossRef] [PubMed]

76. Onoue, S.; Yamada, S.; Yajima, T. Bioactive analogues and drug delivery systems of vasoactive intestinal peptide (VIP) for the treatment of asthma/COPD. Peptides 2007, 28, 1640-1650. [CrossRef]

77. Huang, M.C.; Miller, A.L.; Wang, W.; Kong, Y.; Paul, S.; Goetzl, E.J. Differential signaling of T cell generation of IL-4 by wild-type and short-deletion variant of type $2 \mathrm{G}$ protein-coupled receptor for vasoactive intestinal peptide (VPAC2). J. Immunol. 2006, 176, 6640-6646. [CrossRef]

78. Ghatei, M.A.; Springall, D.R.; Richards, I.M.; Oostveen, J.A.; Griffin, R.L.; Cadieux, A.; Polak, J.M.; Bloom, S.R. Regulatory peptides in the respiratory tract of Macaca fascicularis. Thorax 1987, 42, 431-439. [CrossRef]

79. Baraniuk, J.N.; Lundgren, J.D.; Okayama, M.; Mullol, J.; Merida, M.; Shelhamer, J.H.; Kaliner, M.A. Vasoactive intestinal peptide in human nasal mucosa. J. Clin. Investig. 1990, 86, 825-831. [CrossRef] [PubMed]

80. Howarth, P.H.; Springall, D.R.; Redington, A.E.; Djukanovic, R.; Holgate, S.T.; Polak, J.M. Neuropeptide-containing nerves in endobronchial biopsies from asthmatic and nonasthmatic subjects. Am. J. Respir. Cell. Mol. Biol. 1995, 13, 288-296. [CrossRef]

81. Chanez, P.; Springall, D.; Vignola, A.M.; Moradoghi-Hattvani, A.; Polak, J.M.; Godard, P.; Bousquet, J. Bronchial mucosal immunoreactivity of sensory neuropeptides in severe airway diseases. Am. J. Respir. Crit. Care Med. 1998, 158, 985-990. [CrossRef]

82. Groneberg, D.A.; Springer, J.; Fischer, A. Vasoactive intestinal polypeptide as mediator of asthma. Pulm. Pharmacol. Ther. 2001, 14, 391-401. [CrossRef]

83. Verma, A.K.; Manohar, M.; Upparahalli Venkateshaiah, S.; Mishra, A. Neuroendocrine cells derived chemokine vasoactive intestinal polypeptide (VIP) in allergic diseases. Cytokine Growth Factor. Rev. 2017, 38, 37-48. [CrossRef]

84. Metwali, A.; Blum, A.M.; Ferraris, L.; Klein, J.S.; Fiocchi, C.; Weinstock, J.V. Eosinophils within the healthy or inflamed human intestine produce substance P and vasoactive intestinal peptide. J. Neuroimmunol. 1994, 52, 69-78. [CrossRef]

85. Wershil, B.K.; Turck, C.W.; Sreedharan, S.P.; Yang, J.; An, S.; Galli, S.J.; Goetzl, E.J. Variants of vasoactive intestinal peptide in mouse mast cells and rat basophilic leukemia cells. Cell Immunol. 1993, 151, 369-378. [CrossRef] 
86. Leceta, J.; Martínez, C.; Delgado, M.; Garrido, E.; Gomariz, R.P. Expression of vasoactive intestinal peptide in lymphocytes: A possible endogenous role in the regulation of the immune system. Adv. Neuroimmunol. 1996, 6, 29-36. [CrossRef]

87. Gonzalez-Rey, E.; Delgado, M. Role of vasoactive intestinal peptide in inflammation and autoimmunity. Curr. Opin. Investig. Drugs 2005, 6, 1116-1123. [PubMed]

88. Sergejeva, S.; Hoshino, H.; Yoshihara, S.; Kashimoto, K.; Lötvall, J.; Lindén, A. A synthetic VIP peptide analogue inhibits neutrophil recruitment in rat airways in vivo. Regul. Pept. 2004, 117, 149-154. [CrossRef]

89. Szema, A.M.; Hamidi, S.A.; Koller, A.; Martin, D.W. Vasoactive Intestinal Peptide Knockout (VIP KO) mouse model of sulfitesensitive asthma: Up-regulation of novel lung carbonyl reductase. BMC Immunol. 2011, 12, 66. [CrossRef]

90. Liu, L.; Yen, J.H.; Ganea, D. A novel VIP signaling pathway in T cells cAMP->protein tyrosine phosphatase (SHP-2?)$>$ JAK2/STAT4->Th1 differentiation. Peptides 2007, 28, 1814-1824. [CrossRef]

91. Goetzl, E.J.; Voice, J.K.; Shen, S.; Dorsam, G.; Kong, Y.; West, K.M.; Morrison, C.F.; Harmar, A.J. Enhanced delayed-type hypersensitivity and diminished immediate-type hypersensitivity in mice lacking the inducible VPAC(2) receptor for vasoactive intestinal peptide. Proc. Natl. Acad. Sci. USA 2001, 98, 13854-13859. [CrossRef] [PubMed]

92. Huang, M.; Wu, J.; Dong, J. Modified BuShenYiQi formula alleviates experimental allergic asthma in mice by negative regulation of type 2 innate lymphoid cells and CD4+ type 9 helper T cells and the VIP-VPAC2 signalling pathway. Pharm. Biol. 2021, 59, 1216-1232. [CrossRef]

93. Voice, J.K.; Dorsam, G.; Lee, H.; Kong, Y.; Goetzl, E.J. Allergic diathesis in transgenic mice with constitutive T cell expression of inducible vasoactive intestinal peptide receptor. FASEB J. 2001, 15, 2489-2496. [CrossRef] [PubMed]

94. Lindén, A.; Hansson, L.; Andersson, A.; Palmqvist, M.; Arvidsson, P.; Löfdahl, C.G.; Larsson, P.; Lötvall, J. Bronchodilation by an inhaled VPAC(2) receptor agonist in patients with stable asthma. Thorax 2003, 58, 217-221. [CrossRef]

95. Szema, A.M.; Hamidi, S.A.; Lyubsky, S.; Dickman, K.G.; Mathew, S.; Abdel-Razek, T.; Chen, J.J.; Waschek, J.A.; Said, S.I. Mice lacking the VIP gene show airway hyperresponsiveness and airway inflammation, partially reversible by VIP. Am. J. Physiol. Lung Cell. Mol. Physiol. 2006, 291, L880-L886. [CrossRef]

96. Carter, M.S.; Krause, J.E. Structure, Expression, and Some Regulatory Mechanisms of the Rat Preprotachykinin Gene Encoding Substance P, Neurokinin A, Neuropeptide K, and Neuropeptide Gamma. J. Neurosci. 1990, 10, 2203-2214. [CrossRef]

97. Page, N.M. Characterization of the Gene Structures, Precursor Processing and Pharmacology of the Endokinin Peptides. Vascul. Pharmacol. 2006, 45, 200-208. [CrossRef] [PubMed]

98. Klassert, T.E.; Sánchez, J.J.; Almeida, T.A.; Candenas, L.; Pinto, F.; Acosta, O.; Hernández, M. Common Variants of the Neuropeptide Expressing Tachykinin Genes and Susceptibility to Asthma: A Case-Control Study. J. Neuroimmunol. 2010, $227,202-207$. [CrossRef]

99. Page, N.M.; Bell, N.J.; Gardiner, S.M.; Manyonda, I.T.; Brayley, K.J.; Strange, P.G.; Lowry, P.J. Characterization of the Endokinins: Human Tachykinins with Cardiovascular Activity. Proc. Natl. Acad. Sci. USA 2003, 100, 6245-6250. [CrossRef] [PubMed]

100. Taracanova, A.; Alevizos, M.; Karagkouni, A.; Weng, Z.; Norwitz, E.; Conti, P.; Leeman, S.E.; Theoharides, T.C. SP and IL-33 Together Markedly Enhance TNF Synthesis and Secretion from Human Mast Cells Mediated by the Interaction of Their Receptors. Proc. Natl. Acad. Sci. USA 2017, 114, E4002-E4009. [CrossRef]

101. Lindén, A. Role of Interleukin-17 and the Neutrophil in Asthma. Int. Arch. Allergy Immunol. 2001, 126, 179-184. [CrossRef]

102. Mizuta, K.; Gallos, G.; Zhu, D.; Mizuta, F.; Goubaeva, F.; Xu, D.; Panettieri, R.A., Jr.; Yang, J.; Emala, C.W., Sr. Expression and coupling of neurokinin receptor subtypes to inositol phosphate and calcium signaling pathways in human airway smooth muscle cells. Am. J. Physiol. Lung Cell. Mol. Physiol. 2008, 294, L523-L534. [CrossRef]

103. Schelfhout, V.; Louis, R.; Lenz, W.; Heyrman, R.; Pauwels, R.; Joos, G. The Triple Neurokinin-Receptor Antagonist CS-003 Inhibits Neurokinin A-Induced Bronchoconstriction in Patients with Asthma. Pulm. Pharmacol. Ther. 2006, 19, 413-418. [CrossRef]

104. Lundberg, J.M.; Brodin, E.; Saria, A. Effects and Distribution of Vagal Capsaicin-Sensitive Substance P Neurons with Special Reference to the Trachea and Lungs. Acta Physiol. Scand. 1983, 119, 243-252. [CrossRef]

105. Lundberg, J.M.; Hökfelt, T.; Martling, C.R.; Saria, A.; Cuello, C. Substance P-Immunoreactive Sensory Nerves in the Lower Respiratory Tract of Various Mammals Including Man. Cell Tissue Res. 1984, 235, 251-261. [CrossRef]

106. Carr, M.J.; Hunter, D.D.; Jacoby, D.B.; Undem, B.J. Expression of Tachykinins in Nonnociceptive Vagal Afferent Neurons during Respiratory Viral Infection in Guinea Pigs. Am. J. Respir. Crit. Care Med. 2002, 165, 1071-1075. [CrossRef]

107. Hunter, D.D.; Myers, A.C.; Undem, B.J. Nerve Growth Factor-Induced Phenotypic Switch in Guinea Pig Airway Sensory Neurons. Am. J. Respir. Crit. Care Med. 2000, 161, 1985-1990. [CrossRef]

108. Luts, A.; Uddman, R.; Alm, P.; Basterra, J.; Sundler, F. Peptide-Containing Nerve Fibers in Human Airways: Distribution and Coexistence Pattern. Int. Arch. Allergy Immunol. 1993, 101, 52-60. [CrossRef] [PubMed]

109. Chu, H.W.; Kraft, M.; Krause, J.E.; Rex, M.D.; Martin, R.J. Substance P and Its Receptor Neurokinin 1 Expression in Asthmatic Airways. J. Allergy Clin. Immunol. 2000, 106, 713-722. [CrossRef] [PubMed]

110. Maghni, K.; Michoud, M.-C.; Alles, M.; Rubin, A.; Govindaraju, V.; Meloche, C.; Martin, J.G. Airway Smooth Muscle Cells Express Functional Neurokinin-1 Receptors and the Nerve-Derived Preprotachykinin-a Gene: Regulation by Passive Sensitization. Am. J. Respir. Cell Mol. Biol. 2003, 28, 103-110. [CrossRef] [PubMed]

111. Aliakbari, J.; Sreedharan, S.P.; Turck, C.W.; Goetzl, E.J. Selective Localization of Vasoactive Intestinal Peptide and Substance P in Human Eosinophils. Biochem. Biophys. Res. Commun. 1987, 148, 1440-1445. [CrossRef] 
112. Ho, W.Z.; Lai, J.P.; Zhu, X.H.; Uvaydova, M.; Douglas, S.D. Human Monocytes and Macrophages Express Substance P and Neurokinin-1 Receptor. J. Immunol. Baltim. Md 1950 1997, 159, 5654-5660.

113. Lai, J.P.; Douglas, S.D.; Ho, W.Z. Human Lymphocytes Express Substance P and Its Receptor. J. Neuroimmunol. 1998, 86, 80-86. [CrossRef]

114. Lambrecht, B.N.; Germonpré, P.R.; Everaert, E.G.; Carro-Muino, I.; De Veerman, M.; de Felipe, C.; Hunt, S.P.; Thielemans, K.; Joos, G.F.; Pauwels, R.A. Endogenously Produced Substance P Contributes to Lymphocyte Proliferation Induced by Dendritic Cells and Direct TCR Ligation. Eur. J. Immunol. 1999, 29, 3815-3825. [CrossRef]

115. De Swert, K.O.; Joos, G.F. 9 - Role of Tachykinins in Asthma and Allergic Disease. In New Insights to Neuroimmune Biology; Berczi, I., Ed.; Elsevier: London, UK, 2010; pp. 177-192. ISBN 978-0-12-384691-4.

116. Severini, C.; Improta, G.; Falconieri-Erspamer, G.; Salvadori, S.; Erspamer, V. The Tachykinin Peptide Family. Pharmacol. Rev. 2002, 54, 285-322. [CrossRef]

117. Borbély, É.; Helyes, Z. Role of Hemokinin-1 in Health and Disease. Neuropeptides 2017, 64, 9-17. [CrossRef]

118. Mashaghi, A.; Marmalidou, A.; Tehrani, M.; Grace, P.M.; Pothoulakis, C.; Dana, R. Neuropeptide Substance P and the Immune Response. Cell. Mol. Life Sci. CMLS 2016, 73, 4249-4264. [CrossRef]

119. Chapman, R.W.; Hey, J.A.; McLeod, R.; Minnicozzi, M.; Rizzo, C. Tachykinins in the Lungs. Drug News Perspect. 1998, 11, 480-489.

120. Choi, J.Y.; Khansaheb, M.; Joo, N.S.; Krouse, M.E.; Robbins, R.C.; Weill, D.; Wine, J.J. Substance P Stimulates Human Airway Submucosal Gland Secretion Mainly via a CFTR-Dependent Process. J. Clin. Investig. 2009, 119, 1189-1200. [CrossRef]

121. Khansaheb, M.; Choi, J.Y.; Joo, N.S.; Yang, Y.-M.; Krouse, M.; Wine, J.J. Properties of Substance P-Stimulated Mucus Secretion from Porcine Tracheal Submucosal Glands. Am. J. Physiol. Lung Cell. Mol. Physiol. 2011, 300, L370-L379. [CrossRef]

122. Thapaliya, M.; Chompunud Na Ayudhya, C.; Amponnawarat, A.; Roy, S.; Ali, H. Mast Cell-Specific MRGPRX2: A Key Modulator of Neuro-Immune Interaction in Allergic Diseases. Curr. Allergy Asthma Rep. 2021, 21, 3. [CrossRef]

123. Evans, T.W.; Dixon, C.M.; Clarke, B.; Conradson, T.B.; Barnes, P.J. Comparison of Neurokinin A and Substance P on Cardiovascular and Airway Function in Man. Br. J. Clin. Pharmacol. 1988, 25, 273-275. [CrossRef]

124. Hajna, Z.; Borbély, É.; Kemény, Á.; Botz, B.; Kereskai, L.; Szolcsányi, J.; Pintér, E.; Paige, C.J.; Berger, A.; Helyes, Z. Hemokinin-1 Is an Important Mediator of Endotoxin-Induced Acute Airway Inflammation in the Mouse. Peptides 2015, 64, 1-7. [CrossRef] [PubMed]

125. Grobman, M.; Graham, A.; Outi, H.; Dodam, J.R.; Reinero, C.R. Chronic Neurokinin-1 Receptor Antagonism Fails to Ameliorate Clinical Signs, Airway Hyper-Responsiveness or Airway Eosinophilia in an Experimental Model of Feline Asthma. J. Feline Med. Surg. 2016, 18, 273-279. [CrossRef] [PubMed]

126. Keith, I.M.; Pelto-Huikko, M.; Schalling, M.; Hökfelt, T. Calcitonin gene-related peptide and its mRNA in pulmonary neuroendocrine cells and ganglia. Histochemistry 1991, 96, 311-315. [CrossRef]

127. Kajekar, R.; Myers, A.C. Calcitonin gene-related peptide affects synaptic and membrane properties of bronchial parasympathetic neurons. Respir. Physiol. Neurobiol. 2008, 160, 28-36. [CrossRef]

128. Kuo, H.P.; Rohde, J.; Tokuyama, K.; Barnes, P.J.; Rogers, D.F. Capsaicin and sensory neuropeptide stimulation of goblet cell secretion in Guinea-pig trachea. J. Physiol. 1990, 431, 629-641. [CrossRef] [PubMed]

129. Kay, A.B.; Ali, F.R.; Heaney, L.G.; Benyahia, F.; Soh, C.P.C.; Renz, H.; Lee, T.H.; Larché, M. Airway expression of calcitonin gene-related peptide in T-cell peptide induced late asthmatic reactions in atopics. Allergy 2007, 62, 495-503. [CrossRef]

130. Atanasova, K.R.; Reznikov, L.R. Neuropeptides in asthma, chronic obstructive pulmonary disease and cystic fibrosis. Respir. Res. 2018, 19, 149. [CrossRef]

131. Tschirhart, E.; Bertrand, C.; Theodorsson, E.; Landry, Y. Evidence for the involvement of calcitonin gene-related peptide in the epithelium dependent contraction of Guinea-pig trachea in response to capsaicin. Naunyn Schmiedeberg's Arch. Pharmacol. 1990, 342, 177-181. [CrossRef]

132. Kanemura, T.; Tamaoki, J.; Horii, S.; Saka, N.; Kobayashi, K.; Isono, K.; Takeuchi, S.; Takizawa, T. Calcitonin gene-related peptide augments parasympathetic contraction of rabbit tracheal smooth muscle in vitro. Agents Actions 1990, 31, 219-224. [CrossRef]

133. Dakhama, A.; Kanehiro, A.; Mäkelä, M.J.; Loader, J.E.; Larsen, G.L.; Gelfand, E.W. Regulation of airway hyperresponsiveness by calcitonin gene related peptide in allergen sensitized and challenged mice. Am. J. Respir. Crit. Care Med. 2002, 165, 1137-1144. [CrossRef]

134. Rochlitzer, S.; Veres, T.Z.; Kühne, K.; Prenzler, F.; Pilzner, C.; Knothe, S.; Winkler, C.; Lauenstein, H.-D.; Willart, M.; Hammad, H.; et al. The neuropeptide calcitonin gene-related peptide affects allergic airway inflammation by modulating dendritic cell function. Clin. Exp. Allergy 2011, 41, 1609-1621. [CrossRef]

135. Sood, A.; Shore, S.A. Adiponectin, Leptin, and Resistin in Asthma: Basic Mechanisms through Population Studies. J. Allergy 2013, 2013, 785835. [CrossRef]

136. Bianco, A.; Nigro, E.; Monaco, M.L.; Matera, M.G.; Scudiero, O.; Mazzarella, G.; Daniele, A. The burden of obesity in asthma and COPD: Role of adiponectin. Pulm. Pharmacol. Therap. 2017, 43, 20-25. [CrossRef]

137. Miller, M.; Cho, J.Y.; Pham, A.; Ramsdell, J.; Broide, D.H. Adiponectin and functional adiponectin receptor 1 are expressed by airway epithelial cells in chronic obstructive pulmonary disease. J. Immunol. 2009, 182, 684-691. [CrossRef]

138. Nakanishi, K.; Takeda, Y.; Tetsumoto, S.; Iwasaki, T.; Tsujino, K.; Kuhara, H.; Jin, Y.; Nagatomo, I.; Kida, H.; Goya, S.; et al Involvement of endothelial apoptosis underlying chronic obstructive pulmonary disease-like phenotype in adiponectin-null mice: Implications for therapy. Am. J. Respir. Crit. Care Med. 2011, 183, 1164-1175. [CrossRef] 
139. Takeuchi, T.; Misaki, A.; Fujita, J.; Sonobe, H.; Ohtsuki, Y. T-cadherin (CDH13, Hcadherin) expression downregulated surfactant protein D in bronchioloalveolar cells. Virchows Arch. 2001, 438, 370-375. [CrossRef]

140. Hug, C.; Wang, J.; Ahmad, N.S.; Bogan, J.S.; Tsao, T.S.; Lodish, H.F. T- cadherin is a receptor for hexameric and high-molecularweight forms of Acrp30/adiponectin. Proc. Natl. Acad. Sci. USA 2004, 101, 10308-10313. [CrossRef]

141. Williams, A.S.; Kasahara, D.I.; Verbout, N.G.; Fedulov, A.V.; Zhu, M.; Si, H.; Wurmbrand, A.P.; Hug, C.; Ranscht, B.; Shore, S.A. Role of the adiponectin binding protein, T-cadherin (Cdh13), in allergic airways responses in mice. PLoS ONE 2012, 7, e41088. [CrossRef]

142. Ajuwon, K.M.; Spurlock, M.E. Adiponectin inhibits LPS-induced NF- $\kappa$ B activation and IL-6 production and increases PPAR $\gamma 2$ expression in adipocytes. Am. J. Physiol. Regulat. Integr. Comp. Physiol. 2005, 288, R1220-R1225. [CrossRef]

143. Wulster-Radcliffe, M.C.; Ajuwon, K.M.; Wang, J.; Christian, J.A.; Spurlock, M.E. Adiponectin differentially regulates cytokines in porcine macrophages. Biochem. Biophys. Res. Commun. 2004, 316, 924-929. [CrossRef]

144. Aydin, M.; Koca, C.; Ozol, D.; Uysal, S.; Yildirim, Z.; Sahin Kavakli, H.; Yigitoglu, M.R. Interaction of Metabolic Syndrome with Asthma in Postmenopausal Women: Role of Adipokines. Inflammation 2013, 36, 1232-1238. [CrossRef]

145. Coffey, M.J.; Torretti, B.; Mancuso, P. Adipokines and Cysteinyl Leukotrienes in the Pathogenesis of Asthma. J. Allergy 2015, 157919. [CrossRef] [PubMed]

146. Giouleka, P.; Papatheodorou, G.; Lyberopoulos, P.; Karakatsani, A.; Alchanatis, M.; Roussos, C.; Papiris, S.; Loukides, S. Body mass index is associated with leukotriene inflammation in asthmatics. Eur. J. Clin. Investig. 2011, 41, 30-38. [CrossRef]

147. Matsumoto, Y.; Toyomasu, K.; Uchimura, N.; Ishitake, T. Low-molecular-weight adiponectin is more closely associated with episodes of asthma than high-molecular-weight adiponectin. Endocr. J. 2013, 60, 119-125. [CrossRef]

148. Nigro, E.; Daniele, A.; Scudiero, O.; Monaco, M.L.; Roviezzo, F.; D’Agostino, B.; Mazzarella, G.; Bianco, A. Adiponectin in asthma: Implications for phenotyping. Curr. Protein Pept. Sci. 2015, 16, 182-187. [CrossRef] [PubMed]

149. Sood, A.; Seagrave, J.; Herbert, G.; Harkins, M.; Qualls, C.; Schuyler, M. Asthma is associated with lower adiponectin concentrations in sputum than controls. Am. J. Respir. Crit. Care Med. 2012, 185. abstract (11)A6502.

150. Sood, A.; Qualls, C.; Schuyler, M.; Thyagarajan, B.; Steffes, M.W.; Smith, L.J.; Jacobs, D.R., Jr. Low Serum Adiponectin Predicts Future Risk for Asthma in Women. Am. J. Respir. Crit. Care Med. 2012, 186, 41-47. [CrossRef]

151. Baek, H.-S.; Kim, Y.-D.; Shin, J.-H.; Kim, J.-H.; Oh, J.-W.; Lee, H.-B. Serum leptin and adiponectin levels correlate with exerciseinduced bronchoconstriction in children with asthma. Ann. Allergy Asthma Immunol. 2011, 107, 14-21. [CrossRef]

152. Dogru, M.; Ozde, S.; Aktas, A.; Karatoprak, E.Y. The adiponectin levels and asthma control in non-obese children with asthma. J. Asthma 2015, 52, 772-776. [CrossRef]

153. Kattan, M.; Kumar, R.; Bloomberg, G.R.; Mitchell, H.E.; Calatroni, A.; Gergen, P.J.; Kercsmar, C.M.; Visness, C.M.; Matsui, E.C.; Steinbach, S.F.; et al. Asthma control, adiposity, and adipokines among inner-city adolescents. J. Allergy Clin. Immunol. 2010, 125, 584-592. [CrossRef]

154. Nagel, G.; Koenig, W.; Rapp, K.; Wabitsch, M.; Zoellner, I.; Weiland, S.K. Associations of adipokines with asthma, rhinoconjunctivitis, and eczema in German schoolchildren. Pediatr. Allergy Immunol. 2009, 20, 81-88. [CrossRef] [PubMed]

155. Rothenbacher, D.; Weyermann, M.; Fantuzziw, G.; Brenner, H. Adipokines in cord blood and risk of wheezing disorders within the first two years of life. Clin. Exp. Allergy 2007, 37, 1143-1149. [CrossRef]

156. Sood, A.; Cui, X.; Qualls, C.; Beckett, W.S.; Gross, M.D.; Steffes, M.W.; Smith, L.J.; Jacobs, D.R., Jr. Association between asthma and serum adiponectin concentration in women. Thorax 2008, 63, 877-882. [CrossRef] [PubMed]

157. Ding, Y.; Yang, H.; He, H.; Shi, H.; He, P.; Yan, S.; Jin, T. Plasma Adiponectin Concentrations and Adiponectin Gene Polymorphisms Are Associated with Bronchial Asthma in the Chinese Li Population. Iran J. Allergy Asthma Immunol. 2015, 14, $292-297$.

158. Baltieri, L.; Cazzo, E.; Modena, D.A.O.; Gobato-Rentel, R.C.; Martins, L.C.; Chaim, E.A. Correlation between levels of adipokines and inflammatory mediators with spirometric parameters in individuals with obesity and symptoms of asthma: Cross-sectional study. Pulmonology 2020, 16. [CrossRef]

159. Kalmarzi, R.N.; Ataee, P.; Mansori, M.; Moradi, G.; Ahmadi, S.; Kaviani, Z.; Khalafi, B.; Kooti, W. Serum levels of adiponectin and leptin in asthmatic patients and its relation with asthma severity, lung function and BMI. Allergol. Immunopathol. (Madr) 2017, 45, 258-264. [CrossRef]

160. Mikalsen, I.B.; Byberg, K.; Forman, M.R.; Øymar, K. Adipokines in adolescence; the associations with lung function and atopy - A cross-sectional study. Respir. Med. 2020, 170, 106063. [CrossRef]

161. Nigro, E.; Matteis, M.; Roviezzo, F.; Mattera Iacono, V.; Scudiero, O.; Spaziano, G.; Tartaglione, G.; Urbanek, K.; Filosa, R.; Daniele, A.; et al. Role of adiponectin in sphingosine-1-phosphate induced airway hyperresponsiveness and inflammation. Pharmacol. Res. 2016, 103, 114-122. [CrossRef]

162. Shore, S.A.; Terry, R.D.; Flynt, L.; Xu, A.; Hug, C. Adiponectin attenuates allergen-induced airway inflammation and hyperresponsiveness in mice. J. Allergy Clin. Immunol. 2006, 118, 389-395. [CrossRef]

163. Otelea, M.R.; Arghir, O.C.; Zugravu, C.; Rascu, A. Adiponectin and Asthma: Knowns, Unknowns and Controversies. Int. J. Mol. Sci. 2021, 22, 8971. [CrossRef]

164. Hsu, A.; Aronoff, D.M.; Phipps, J.; Goel, D.; Mancuso, P. Leptin improves pulmonary bacterial clearance and survival in ob/ob mice during pneumococcal pneumonia. Clin. Exp. Immunol. 2007, 150, 332-339. [CrossRef]

165. Mancuso, P.; Gottschalk, A.; Phare, S.M.; Peters-Golden, M.; Lukacs, N.W.; Huffnagle, G.B. Leptin-deficient mice exhibit impaired host defense in Gram-negative pneumonia. J. Immunol. 2002, 168, 4018-4024. [CrossRef] [PubMed] 
166. Forny-Germano, L.; De Felice, F.G.; Vieira, M.N. The Role of Leptin and Adiponectin in Obesity-Associated Cognitive Decline and Alzheimer's Disease. Front. Neurosci. 2019, 12, 1027. [CrossRef]

167. Ducy, P.; Amling, M.; Takeda, S.; Priemel, M.; Schilling, A.F.; Beil, F.T.; Shen, J.; Vinson, C.; Rueger, J.M.; Karsenty, G. Leptin inhibits bone formation through a hypothalamic relay: A central control of bone mass. Cell 2000, 100, 197-207. [CrossRef]

168. Matarese, G.; Moschos, S.; Mantzoros, C.S. Leptin in immunology. J. Immunol. 2005, 174, 3137-3142. [CrossRef]

169. Vernooy, J.H.J.; Ubags, N.D.J.; Brusselle, G.G.; Tavernier, J.; Suratt, B.T.; Joos, G.F.; Wouters, E.F.M.; Bracke, K.R. Leptin as regulator of pulmonary immune responses: Involvement in respiratory diseases. Pulm. Pharmacol. Ther. 2013, 26, 464-472. [CrossRef]

170. Bruno, A.; Pace, E.; Chanez, P.; Gras, D.; Vachier, I.; Chiappara, G.; La Guardia, M.; Gerbino, S.; Profita, M.; Gjomarkaj, M. Leptin and leptin receptor expression in asthma. J. Allergy Clin. Immunol. 2009, 124, 230-237. [CrossRef]

171. Holguin, F.; Rojas, M.; Brown, L.; Fitzpatrick, A.M. Airway and Plasma Leptin and Adiponectin in Lean and Obese Asthmatics and Controls. J. Asthma 2011, 48, 217-223. [CrossRef]

172. Nair, P.; Radford, K.; Fanat, A.; Janssen, L.J.; Peters-Golden, M.; Cox, P.G. The effects of leptin on airway smooth muscle responses. Am. J. Respir. Cell. Mol. Biol. 2008, 39, 475-481. [CrossRef]

173. Cvejoska Cholakovska, V.; Vlashki, E.; Kochova, M.; Velikj Stefanovska, V.; Petlichkovski, A. Leptin, Obesity Parameters, and Atopy among Children with Asthma. Pril (Makedon Akad Nauk Umet Odd Med Nauki) 2021, 42, 79-88. [CrossRef]

174. Doaa, M.Y.; Rabab, M.E.; Dina, M.S.; Eman, M.E. The influence of leptin on Th1/Th2 balance in obese children with asthma. J. Bras. Pneumol. 2013, 39, 562-568.

175. Lessard, A.; St-Laurent, J.; Turcotte, H.; Boulet, L.-P. Leptin and adiponectin in obese and non-obese subjects with asthma. Biomarkers 2011, 16, 271-273. [CrossRef]

176. Ma, C.; Wang, Y.; Xue, M. Correlations of severity of asthma in children with body mass index, adiponectin and leptin. J. Clin. Lab. Anal. 2019, 33, e22915. [CrossRef]

177. Morishita, R.; do Carmo Franco, M.; Suano-Souza, F.I.; Solé, D.; Fiorini Puccini, R.; Louzada Strufaldi, M.W. Body mass index, adipokines and insulin resistance in asthmatic children and adolescents. J. Asthma 2016, 53, 478-484. [CrossRef]

178. Newson, R.B.; Jones, M.; Forsberg, B.; Janson, C.; Bossios, A.; Dahlen, S.-E.; Toskala, E.M.; Al-Kalemji, A.; Kowalski, M.L.; Rymarczyk, B.; et al. The association of asthma, nasal allergies, and positive skin prick tests with obesity, leptin, and adiponectin. Clin. Exp. Allergy 2014, 44, 250-260. [CrossRef]

179. Tanju, A.; Cekmez, F.; Aydinoz, S.; Karademir, F.; Suleymanoglu, S.; Gocmen, I. Association Between Clinical Severity of Childhood Asthma and Serum Leptin Levels. Indian J. Pediatr. 2011, 78, 291-295. [CrossRef]

180. Leivo-Korpela, S.; Lehtimäki, L.; Vuolteenaho, K.; Nieminen, R.; Kankaanranta, H.; Saarelainen, S.; Moilanen, E. Adipokine resistin predicts anti-inflammatory effect of glucocorticoids in asthma. J. Inflamm. (Lond.) 2011, 8, 12. [CrossRef]

181. Leão da Silva, P.; de Mello, M.T.; Cheik, N.C.; Sanches, P.L.; Munhoz da Silveira Campos, R.; Carnier, J.; Inoue, D.; do Nascimento, C.M.; Oyama, L.M.; Tock, L.; et al. Reduction in the leptin concentration as a predictor of improvement in lung function in obese adolescents. Obes. Facts 2012, 5, 806-820. [CrossRef]

182. Al-Ayed, M.; Alshaybari, K.; Alshehri, J.A.; Nasser, I.; Alaamri, H.; Alaseeri, W.; Mahfouz, A.A.; Alsareli, S.A.; Asaad, A.M.; Magzoub, A.A.; et al. Obesity and childhood asthma in male schoolchildren in Saudi Arabia: Is there a role for leptin, interleukin-4, interleukin-5, and interleukin-21? Ann. Saudi. Med. 2019, 39, 295-301. [CrossRef]

183. Vassiliou, A.G.; Vitsas, V.; Kardara, M.; Keskinidou, C.; Michalopoulou, P.; Rovina, N.; Dimopoulou, I.; Orfanos, S.E.; Tsoukalas, G.; Koutsoukou, A.; et al. Study of inflammatory biomarkers in COPD and asthma exacerbations. Adv. Respir. Med. 2020, 88, 558-566. [CrossRef]

184. Castro-Rodriguez, J.A.; Forno, E.; Casanello, P.; Padilla, O.; Krause, B.J.; Uauy, R. Leptin in Cord Blood Associates with Asthma Risk at Age 3 in the Offspring of Gestational Obesity. Ann. Am. Thorac. Soc. 2020, 17, 1583-1589. [CrossRef]

185. Rastogi, D.; Lang, J. Leptin as a Predictor of Incident Asthma in Offspring of Obese Mothers. Ann. Am. Thorac. Soc. 2020, 17, 1530-1532. [CrossRef]

186. Jang, A.-S.; Kim, T.-H.; Park, J.-S.; Kim, K.-U.; Uh, S.-T.; Seo, K.-H.; Kim, Y.H.; Lim, H.I.; Park, C.-S. Association of Serum Leptin and Adiponectin with Obesity in Asthmatics. J. Asthma 2009, 46, 59-63. [CrossRef]

187. Jartti, T.; Saarikoski, L.; Jartti, L.; Lisinen, I.; Jula, A.; Huupponen, R.; Viikari, J.; Raitakari, O.T. Obesity, adipokines and asthma. Allergy 2009, 64, 770-777. [CrossRef]

188. Arshi, M.; Cardinal, J.; Hill, R.J.; Davies, P.S.; Wainwright, C. Asthma and insulin resistance in children. Respirology 2010, 15, 779-784. [CrossRef]

189. Kim, K.W.; Shin, Y.H.; Lee, K.E.; Kim, E.S.; Sohn, M.H.; Kim, K.E. Relationship between adipokines and manifestations of childhood asthma. Pediatr. Allergy Immunol. 2008, 19, 535-540. [CrossRef]

190. Muc, M.; Todo-Bom, A.; Mota-Pinto, A.; Vale-Pereira, S.; Loureiro, C. Leptin and resistin in overweight patients with and without asthma. Allergol. Immunopathol. (Madr) 2014, 42, 415-421. [CrossRef]

191. Sutherland, T.J.T.; Sears, M.R.; McLachlan, C.R.; Poulton, R.; Hancox, R.J. Leptin, adiponectin, and asthma: Findings from a population-based cohort study. Ann. Allergy Asthma Immunol. 2009, 103, 101-107. [CrossRef]

192. Arteaga-Solis, E.; Zee, T.; Emala, C.W.; Vinson, C.; Wess, J.; Karsenty, G. Inhibition of Leptin Regulation of Parasympathetic Signaling as a Cause of Extreme Body Weight-Associated Asthma. Cell Metab. 2013, 17, 35-48. [CrossRef]

193. Polotsky, M.; Elsayed-Ahmed, A.S.; Pichard, L.; Harris, C.C.; Smith, P.L.; Schneider, H.; Kirkness, J.P.; Polotsky, V.; Schwartz, A.R. Effects of leptin and obesity on the upper airway function. J. Appl. Physiol. 2012, 112, 1637-1643. [CrossRef] 
194. Shore, S.A.; Fredberg, J.J. Obesity, smooth muscle, and airway hyperresponsiveness. J. Allergy Clin. Immunol. 2005, 115, 925-927. [CrossRef] [PubMed]

195. Shore, S.A.; Rivera-Sanchez, Y.M.; Schwartzman, I.N.; Johnston, R.A. Responses to ozone are increased in obese mice. J. Appl. Physiol. 2003, 95, 938-945. [CrossRef]

196. Shore, S.A.; Schwartzman, I.N.; Mellema, M.S.; Flynt, L.; Imrich, A.; Johnston, R.A. Effect of leptin on allergic airway responses in mice. J. Allergy Clin. Immunol. 2005, 115, 103-109. [CrossRef]

197. Lu, F.L.; Johnston, R.A.; Flynt, L.; Theman, T.A.; Terry, R.D.; Schwartzman, I.N.; Lee, A.; Shore, S.A. Increased pulmonary responses to acute ozone exposure in obese db/db mice. Am. J. Physiol. Lung Cell. Mol. Physiol. 2006, 290, L856-L865. [CrossRef]

198. Johnston, R.A.; Theman, T.A.; Lu, F.L.; Terry, R.D.; Williams, E.S.; Shore, S.A. Diet-induced obesity causes innate airway hyperresponsiveness to methacholine and enhances ozone-induced pulmonary inflammation. J. Appl. Physiol. 2008, 104, 1727-1735. [CrossRef] [PubMed]

199. Wong, C.K.; Cheung, P.F.; Lam, C.W. Leptin-mediated cytokine release and migration of eosinophils: Implications for immunopathophysiology of allergic inflammation. Eur. J. Immunol. 2007, 37, 2337-2348. [CrossRef]

200. Steppan, C.M.; Bailey, S.T.; Bhat, S.; Brown, E.J.; Banerjee, R.R.; Wright, C.M.; Patel, H.R.; Ahima, R.S.; Lazar, M.A. The hormone resistin links obesity to diabetes. Nature 2001, 409, 307-312. [CrossRef] [PubMed]

201. Lehrke, M.; Reilly, M.P.; Millington, S.C.; Iqbal, N.; Rader, D.J.; Lazar, M.A. An inflammatory cascade leading to hyperresistinemia in humans. PLoS Med. 2004, 1, e45. [CrossRef]

202. Larochelle, J.; Freiler, J.; Dice, J.; Hagan, L. Plasma resistin levels in asthmatics as a marker of disease state. J. Asthma 2007, 44, 509-513. [CrossRef]

203. Mishra, A.; Wang, M.; Schlotman, J.; Nikolaidis, N.M.; DeBrosse, C.W.; Karow, M.L.; Rothenberg, M.E. Resistin-like molecule-beta is an allergen-induced cytokine with inflammatory and remodeling activity in the murine lung. Am. J. Physiol. Lung Cell. Mol. Physiol. 2007, 293, L305-L313. [CrossRef]

204. Lin, Q.; Johns, R.A. Resistin family proteins in pulmonary diseases. Am. J. Physiol. Lung Cell. Mol. Physiol. 2020, 319, L422-L434. [CrossRef]

205. Kwak, S.; Kim, Y.D.; Na, H.G.; Bae, C.H.; Song, S.Y.; Choi, Y.S. Resistin upregulates MUC5AC/B mucin gene expression in human airway epithelial cells. Biochem. Biophys. Res. Commun. 2018, 499, 655-661. [CrossRef] [PubMed]

206. Silswal, N.; Singh, A.K.; Aruna, B.; Mukhopadhyay, S.; Ghosh, S.; Ehtesham, N.Z. Human resistin stimulates the pro-inflammatory cytokines TNF-alpha and IL-12 in macrophages by NF-kappaB-dependent pathway. Biochem. Biophys. Res. Commun. 2005, 334, 1092-1101. [CrossRef]

207. Lu, S.C.; Shieh, W.Y.; Chen, C.Y.; Hsu, S.C.; Chen, H.L. Lipopolysaccharide increases resistin gene expression in vivo and in vitro. FEBS Lett. 2002, 530, 158-162. [CrossRef]

208. Hirai, H.; Satoh, H.; Kudoh, A.; Watanabe, T. Interaction between resistin and adiponectin in the proliferation of rat vascular smooth muscle cells. Mol. Cell. Endocrinol. 2013, 366, 108-116. [CrossRef]

209. Filková, M.; Haluzík, M.; Gay, S.; Senolt, L. The role of resistin as a regulator of inflammation: Implications for various human pathologies. Clin. Immunol. 2009, 133, 157-170. [CrossRef]

210. Pang, S.S.; Le, Y.Y. Role of resistin in inflammation and inflammation-related diseases. Cell. Mol. Immunol. 2006, 3, 29-34. [PubMed]

211. Zhang, L.; Wang, M.; Kang, X.; Boontheung, P.; Li, N.; Nel, A.E.; Loo, J.A. Oxidative stress and asthma: Proteome analysis of chitinase-like proteins and FIZZ1 in lung tissue and bronchoalveolar lavage fluid. J. Proteome Res. 2009, 8, 1631-1638. [CrossRef]

212. Dong, L.; Wang, S.J.; Camoretti-Mercado, B.; Li, H.J.; Chen, M.; Bi, W.X. FIZZ1 plays a crucial role in early stage airway remodeling of OVA-induced asthma. J Asthma 2008, 45, 648-653. [CrossRef] [PubMed]

213. Kawashima, S.; Hirose, K.; Takahashi, K.; Tamachi, T.; Ikeda, K.; Tokoyoda, K.; Nakayama, T.; Nakajima, H. Interleukin-25 induces pulmonary arterial remodeling via natural killer T cell-dependent mechanisms. Int. Arch. Allergy Immunol. 2013, 161, 118-124. [CrossRef] [PubMed]

214. Fang, C.; Meng, Q.; Wu, H.; Eid, G.; Zhang, G.; Zhang, X.; Yang, S.; Huang, K.; Lee, T.H.; Corrigan, C.J.; et al. Resistin-like molecule- $\beta$ is a human airway remodelling mediator. Eur. Respir. J. 2012, 39, 458-466. [CrossRef] [PubMed]

215. Fang, C.L.; Yin, L.J.; Sharma, S.; Kierstein, S.; Wu, H.F.; Eid, G.; Haczku, A.; Corrigan, C.J.; Ying, S. Resistin-like molecule- $\beta$ (RELM- $\beta$ ) targets airways fibroblasts to effect remodelling in asthma: From mouse to man. Clin. Exp. Allergy. 2015, 45, 940-952. [CrossRef]

216. Lee, M.R.; Shim, D.; Yoon, J.; Jang, H.S.; Oh, S.W.; Suh, S.H.; Choi, J.H.; Oh, G.T. Retnla overexpression attenuates allergic inflammation of the airway. PLoS ONE 2014, 9, e112666. [CrossRef]

217. Liu, T.; Dhanasekaran, S.M.; Jin, H.; Hu, B.; Tomlins, S.A.; Chinnaiyan, A.M.; Phan, S.H. FIZZ1 stimulation of myofibroblast differentiation. Am. J. Pathol. 2004, 164, 1315-1326. [CrossRef]

218. LeMessurier, K.S.; Palipane, M.; Tiwary, M.; Gavin, B.; Samarasinghe, A.E. Chronic features of allergic asthma are enhanced in the absence of resistin-like molecule-beta. Sci. Rep. 2018, 8, 7061. [CrossRef]

219. Pine, G.M.; Batugedara, H.M.; Nair, M.G. Here, there and everywhere: Resistin-like molecules in infection, inflammation, and metabolic disorders. Cytokine 2018, 110, 442-451. [CrossRef] [PubMed] 
220. Fan, C.; Meuchel, L.W.; Su, Q.; Angelini, D.J.; Zhang, A.; Cheadle, C.; Kolosova, I.; Makarevich, O.D.; Yamaji-Kegan, K.; Rothenberg, M.E.; et al. Resistin-Like Molecule $\alpha$ in Allergen-Induced Pulmonary Vascular Remodeling. Am. J. Respir. Cell. Mol. Biol. 2015, 53, 303-313. [CrossRef]

221. Al Mutairi, S.S.; Mojiminiyi, O.A.; Shihab-Eldeen, A.; Al Rammah, T.; Abdella, N. Putative roles of circulating resistin in patients with asthma, COPD and cigarette smokers. Dis. Markers 2011, 31, 1-7. [CrossRef] [PubMed]

222. Ballantyne, D.; Scott, H.; MacDonald-Wicks, L.; Gibson, P.G.; Wood, L.G. Resistin is a predictor of asthma risk and resistin:adiponectin ratio is a negative predictor of lung function in asthma. Clin. Exp. Allergy 2016, 46, 1056-1065. [CrossRef]

223. Vezir, E.; Civelek, E.; Dibek Misirlioglu, E.; Toyran, M.; Capanoglu, M.; Karakus, E.; Kahraman, T.; Ozguner, M.; Demirel, F.; Gursel, I.; et al. Effects of Obesity on Airway and Systemic Inflammation in Asthmatic Children. Int. Arch. Allergy Immunol. 2021, 182, 679-689. [CrossRef]

224. Grainge, C.; Dulay, V.; Ward, J.; Sammut, D.; Davies, E.; Green, B.; Lau, L.; Cottey, L.; Haitchi, H.M.; Davies, D.E.; et al. Resistin-like molecule- $\beta$ is induced following bronchoconstriction of asthmatic airways. Respirology 2012, 17, 1094-1100. [CrossRef]

225. Baatar, D.; Patel, K.; Taub, D.D. The effects of ghrelin on inflammation and the immune system. Mol. Cell. Endocrinol. 2011, 340, 44-58. [CrossRef]

226. Wang, H.; Yang, T.; Shen, Y.; Wan, C.; Li, X.; Li, D.; Liu, Y.; Wang, T.; Xu, D.; Wen, F.; et al. Ghrelin Inhibits Interleukin-6 Production Induced by Cigarette Smoke Extract in the Bronchial Epithelial Cell Via NF-кB Pathway. Inflammation 2016, 39, 190-198. [CrossRef] [PubMed]

227. Fu, T.; Wang, L.; Zeng, Q.; Zhang, Y.; Sheng, B.; Han, L. Ghrelin Ameliorates Asthma by Inhibiting Endoplasmic Reticulum Stress. Am. J. Med. Sci. 2017, 354, 617-625. [CrossRef] [PubMed]

228. Kojima, M.; Kangawa, K. Ghrelin: Structure and function. Physiol. Rev. 2005, 85, 495-522. [CrossRef] [PubMed]

229. Ueberberg, B.; Unger, N.; Saeger, W.; Mann, K.; Petersenn, S. Expression of ghrelin and its receptor in human tissues. Horm. Metab. Res. 2009, 41, 814-821. [CrossRef]

230. Volante, M.; Fulcheri, E.; Allìa, E.; Cerrato, M.; Pucci, A.; Papotti, M. Ghrelin expression in fetal, infant, and adult human lung. J. Histochem. Cytochem. 2002, 50, 1013-1021. [CrossRef]

231. Wu, R.; Dong, W.; Zhou, M.; Zhang, F.; Marini, C.P.; Ravikumar, T.S.; Wang, P. Ghrelin attenuates sepsis-induced acute lung injury and mortality in rats. Am. J. Respir. Crit. Care Med. 2007, 176, 805-813. [CrossRef]

232. Dixit, V.D.; Schaffer, E.M.; Pyle, R.S.; Collins, G.D.; Sakthivel, S.K.; Palaniappan, R.; Lillard, J.W., Jr.; Taub, D.D. Ghrelin inhibits leptin- and activation-induced proinflammatory cytokine expression by human monocytes and T cells. J. Clin. Investig. 2004, 114, 57-66. [CrossRef] [PubMed]

233. Li, W.G.; Gavrila, D.; Liu, X.; Wang, L.; Gunnlaugsson, S.; Stoll, L.L.; McCormick, M.L.; Sigmund, C.D.; Tang, C.; Weintraub, N.L. Ghrelin inhibits proinflammatory responses and nuclear factor-kappaB activation in human endothelial cells. Circulation 2004, 109, 2221-2226. [CrossRef] [PubMed]

234. Kizaki, T.; Maegawa, T.; Sakurai, T.; Ogasawara, J.E.; Ookawara, T.; Ohishi, S.; Izawa, T.; Haga, S.; Ohno, H. Voluntary exercise attenuates obesity-associated inflammation through ghrelin expressed in macrophages. Biochem. Biophys. Res. Commun. 2011, 413, 454-459. [CrossRef] [PubMed]

235. Wu, R.; Zhou, M.; Das, P.; Dong, W.; Ji, Y.; Yang, D.; Miksa, M.; Zhang, F.; Ravikumar, T.S.; Wang, P. Ghrelin inhibits sympathetic nervous activity in sepsis. Am. J. Physiol. Endocrinol. Metab. 2007, 293, E1697-E1702. [CrossRef]

236. Xia, Q.; Pang, W.; Pan, H.; Zheng, Y.; Kang, J.S.; Zhu, S.G. Effects of ghrelin on the proliferation and secretion of splenic T lymphocytes in mice. Regul. Pept. 2004, 122, 173-178. [CrossRef]

237. Mao, Y.; Zhang, S.; Yu, F.; Li, H.; Guo, C.; Fan, X. Ghrelin Attenuates Liver Fibrosis through Regulation of TGF- $\beta 1$ Expression and Autophagy. Int. J. Mol. Sci. 2015, 16, 21911-21930. [CrossRef]

238. Ota, Y.; Kawaguchi, Y.; Takagi, K.; Ichida, H.; Gono, T.; Hanaoka, M.; Higuchi, T.; Yamanaka, H. Ghrelin attenuates collagen production in lesional fibroblasts from patients with systemic sclerosis. Clin. Immunol. 2013, 147, 71-78. [CrossRef]

239. Zhang, G.G.; Cai, H.Q.; Li, Y.H.; Sui, Y.B.; Zhang, J.S.; Chang, J.R.; Ning, M.; Wu, Y.; Tang, C.S.; Qi, Y.F.; et al. Ghrelin protects heart against ERS-induced injury and apoptosis by activating AMP-activated protein kinase. Peptides 2013, 48, 156-165. [CrossRef] [PubMed]

240. Imazu, Y.; Yanagi, S.; Miyoshi, K.; Tsubouchi, H.; Yamashita, S.; Matsumoto, N.; Ashitani, J.; Kangawa, K.; Nakazato, M. Ghrelin ameliorates bleomycin-induced acute lung injury by protecting alveolar epithelial cells and suppressing lung inflammation. Eur. J. Pharmacol. 2011, 672, 153-158. [CrossRef]

241. Tsubouchi, H.; Yanagi, S.; Miura, A.; Iizuka, S.; Mogami, S.; Yamada, C.; Hattori, T.; Nakazato, M. Rikkunshito ameliorates bleomycin-induced acute lung injury in a ghrelin-independent manner. Am. J. Physiol. Lung Cell. Mol. Physiol. 2014, 306, L233-L245. [CrossRef]

242. Sato, T.; Nakamura, Y.; Shiimura, Y.; Ohgusu, H.; Kangawa, K.; Kojima, M. Structure, regulation and function of ghrelin. J. Biochem. 2012, 151, 119-128. [CrossRef]

243. Wang, H.; Dou, S.; Zhu, J.; Shao, Z.; Wang, C.; Cheng, B. Regulatory effects of ghrelin on endoplasmic reticulum stress, oxidative stress, and autophagy: Therapeutic potential. Neuropeptides 2021, 85, 102112. [CrossRef]

244. Jafari, A.; Sadeghpour, S.; Ghasemnejad-Berenji, H.; Pashapour, S.; Ghasemnejad-Berenji, M. Potential Antioxidative, Antiinflammatory and Immunomodulatory Effects of Ghrelin, an Endogenous Peptide from the Stomach in SARS-CoV2 Infection. Int. J. Pept. Res. Ther. 2021, 16, 1-9. [CrossRef] 
245. Tsaroucha, A.; Daniil, Z.; Malli, F.; Georgoulias, P.; Minas, M.; Kostikas, K.; Bargiota, A.; Zintzaras, E.; Gourgoulianis, K.I. Leptin, adiponectin, and ghrelin levels in female patients with asthma during stable and exacerbation periods. J. Asthma 2013, 50, 188-197. [CrossRef]

246. Yuksel, H.; Sogut, A.; Yilmaz, O.; Onur, E.; Dinc, G. Role of adipokines and hormones of obesity in childhood asthma. Allergy Asthma Immunol. Res. 2012, 4, 98-103. [CrossRef] [PubMed]

247. Matsuda, K.; Nishi, Y.; Okamatsu, Y.; Kojima, M.; Matsuishi, T. Ghrelin and leptin: A link between obesity and allergy? J. Allergy Clin. Immunol. 2006, 117, 705-706. [CrossRef] [PubMed]

248. Al-Ayed, M.S.; Al-Shaibari, K.S.; Alshehri, D.; Alzahrani, M.J.; Nasser, I.; Alaamri, H.S.; Alaseeri, W.A.; Mahfouz, A.A.; Alsareii, S.A.; Asaad, A.M.; et al. Serum Ghrelin Levels in Saudi Obese Asthmatic School-Children-Correlation with Interleukin-4, Interleukin-5, and Interleukin-21. Int. J. Environ. Res. Public Health 2020, 17, 1656. [CrossRef]

249. Toru, Ü.; Ayada, C.; Genç, O.; Şahin, S.; Arık, Ö.; Acat, M.; Bulut, İ.; Çetinkaya, E. Visfatin and ghrelin: Can they be forthcoming biomarkers or new drug targets for asthma? Int. J. Clin. Exp. Med. 2015, 8, 6257-6261. [PubMed]

250. Kodama, T.; Ashitani, J.; Matsumoto, N.; Kangawa, K.; Nakazato, M. Ghrelin treatment suppresses neutrophil-dominant inflammation in airways of patients with chronic respiratory infection. Pulm. Pharmacol. Ther. 2008, 21, 774-779. [CrossRef] [PubMed]

251. Miki, K.; Maekura, R.; Nagaya, N.; Nakazato, M.; Kimura, H.; Murakami, S.; Ohnishi, S.; Hiraga, T.; Miki, M.; Kitada, S.; et al. Ghrelin treatment of cachectic patients with chronic obstructive pulmonary disease: A multicenter, randomized, double-blind, placebo-controlled trial. PLoS ONE 2012, 7, e35708. [CrossRef] [PubMed]

252. Pałgan, K.; Tykwińska, M.; Bartuzi, Z. Antimicrobial peptides in asthma pathogenesis. Postępy Higieny i Medycyny Doświadczalnej 2015, 69, 10-13. [CrossRef]

253. Lecaille, F.; Lalmanach, G.; Andrault, P.M. Antimicrobial proteins and peptides in human lung diseases: A friend and foe partnership with host proteases. Biochimie 2016, 122, 151-168. [CrossRef] [PubMed]

254. Beisswenger, C.; Bals, R. Antimicrobial peptides in lung inflammation. Chem. Immunol. Allergy 2005, 86, 55-71. [CrossRef] [PubMed]

255. Jiao, D.; Wong, C.K.; Tsang, M.S.; Chu, I.M.; Liu, D.; Zhu, J.; Chu, M.; Lam, C.W. Activation of Eosinophils Interacting with Bronchial Epithelial Cells by Antimicrobial Peptide LL-37: Implications in Allergic Asthma. Sci. Rep. 2017, 7, 1848. [CrossRef] [PubMed]

256. Sun, J.; Dahlén, B.; Agerberth, B.; Haeggström, J.Z. The antimicrobial peptide LL-37 induces synthesis and release of cysteinyl leukotrienes from human eosinophils-implications for asthma. Allergy 2013, 68, 304-311. [CrossRef]

257. Buss, W.W.; Lemanske, R.J.; Gern, J.E. Role of viral respiratory infections in asthma and asthma exacerbations. Lancet 2010, 376, 826-834. [CrossRef]

258. Levy, H.; Raby, B.A.; Lake, S.; Tantisira, K.G.; Kwiatkowski, D.; Lazarus, R.; Silverman, E.K.; Richter, B.; Klimecki, W.T.; Vercelli, D.; et al. Association of defensin beta-1 gene polymorphisms with asthma. J. Allergy Clin. Immunol. 2005, 115, 252-258. [CrossRef] [PubMed]

259. Borchers, N.S.; Santos-Valente, E.; Toncheva, A.A.; Wehkamp, J.; Franke, A.; Gaertner, V.D.; Nordkild, P.; Genuneit, J.; Jensen, B.; Kabesch, M. Human $\beta$-Defensin 2 Mutations Are Associated With Asthma and Atopy in Children and Its Application Prevents Atopic Asthma in a Mouse Model. Front. Immunol. 2021, 12, 636061. [CrossRef]

260. Pinkerton, J.W.; Kim, R.Y.; Koeninger, L.; Armbruster, N.S.; Hansbro, N.G.; Brown, A.C.; Jayaraman, R.; Shen, S.; Malek, N.; Cooper, M.A.; et al. Human $\beta$-defensin-2 suppresses key features of asthma in murine models of allergic airways disease. Clin. Exp. Allergy 2021, 51, 120-131. [CrossRef] 